\title{
DiscoverArchive UNIVERSITY
}

Retrieved from DiscoverArchive,

Vanderbilt University's Institutional Repository

This work was originally published as Robin Kundis Craig and JB

Ruhl, Designing Administrative Law for Adaptive Management, in

67 Vanderbilt Law Review 12014. 


\title{
VANDERBILT LAW REVIEW
}

VOLUME 67

JANUARY 2014

NUMBER 1

\section{ARTICLES}

\section{Designing Administrative Law for Adaptive Management}

\author{
Robin Kundis Craig* \\ J.B. Ruhl**
}

Administrative law needs to adapt to adaptive management. Adaptive management is a structured decisionmaking method, the core of which is a multistep, iterative process for adjusting management measures to changing circumstances or new information about the effectiveness of prior measures or the system being managed. It has been identified as a necessary or bestpractices component of regulation in a broad range of fields, including drug and medical-device warnings, financial system regulation, social welfare programs, and natural resources management. Nevertheless, many of the agency decisions advancing these policies remain subject to the requirements of either the federal Administrative Procedure Act or the states' parallel statutes. Adaptive management theorists have identified several features of such administrative law requirements-especially public participation, judicial review, and

* William H. Leary Professor of Law at the University of Utah S.J. Quinney College of Law, Salt Lake City, Utah. Contact: robin.craig@law.utah.edu.

** David Daniels Allen Distinguished Chair in Law, Vanderbilt University Law School, Nashville, Tenn. Contact: jb.ruhl@vanderbilt.edu. We would like to thank Eric Biber, Barbara Cosens, Dave Markell, Kevin Stack, Michael Vandenbergh, and the participants in faculty colloquia at the 2013 Natural Resources Law Teachers Conference, the University of Tulsa College of Law, the University of Utah S.J. Quinney College of Law, and Vanderbilt Law School for their comments on drafts of this article. 
finality—as posing barriers to true adaptive management, but they have put forward no proposals for reform.

This Article represents the first effort in adaptive management theory to go beyond complaining about the handcuffs administrative law puts on adaptive management and to suggest a solution. The Article begins by explaining the theory and limits of adaptive management to emphasize that it is not appropriate for all, or even most, agency decisionmaking. For appropriate applications, however, we argue that conventional administrative law has unnecessarily shackled effective use of adaptive management. We show that through a specialized "adaptive management track" of administrative procedures, the core values of administrative law can be implemented in ways that much better allow for adaptive management. Going further, we propose and explain draft model legislation that would create such a track for the specific types of agency decisionmaking that could benefit from adaptive management.

I. INTRODUCTION .................................................. 3

II. The THEORY AND Limits OF ADAPTIVE MANAGEMENT IN THE ADMINISTRATIVE STATE.................................... 16

A. $\quad$ Successful Adaptive Management in Theory ........... 16

B. $\quad$ Successful Adaptive Management in Practice........... 18

1. Management-Problem Context.................... 19

2. Decisionmaking Environment ................... 21

III. ADMINISTRATIVE LAW: VALUES AND OBSTACLES TO

ADAPTIVE MANAGEMENT ....................................... 27

A. Public Participation ........................................ 28

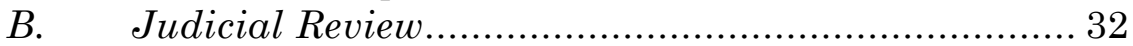

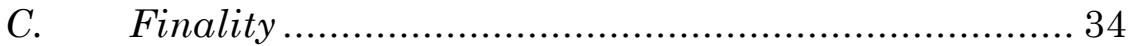

D. A New Approach to Administrative Law ................. 38

IV. ADDING AN ADAPTIVE MANAGEMENT TRACK TO

ADMINISTRATIVE LAW .............................................. 40

A. Preserving Traditional Administrative Law

Values in the Adaptive Management Process........... 41

1. Public Participation ................................. 42

2. Judicial Review ........................................ 44

3. $\quad$ Finality .............................................. 46

B. Designing Administrative Law Specifically for Adaptive Management......................................... 48

1. Getting on the Adaptive Management Track: Three Pathways ............................. 50 
2. Formulating the Initial Adaptive

Management Plan: Goals, Monitoring, and

Standards

3. The Implementation Phase and Emergency

Interventions

4. Resetting at the Pause Point: Review, Evaluation, and the Next Round of

Adaptive Management

5. Getting Off the Adaptive Management

Track Once on It

V. CONCLUSION

VI. APPEndix: The Model Adaptive Management

PROCEDURE ACT

The administrative style that has characterized American public law from the New Deal to the 1980s has been out of favor in recent years.

—Charles Sabel and William Simon ${ }^{1}$

\section{INTRODUCTION}

In the never-ending project to build a better regulatory state mousetrap, two of the most seductive reinvention models to emerge over the past few decades have been market-based regulation ${ }^{2}$ and adaptive management. ${ }^{3}$ Representative of two broad and opposing thrusts of regulatory reform, one advocating "minimalism" 4 and the other

1. Charles F. Sabel \& William H. Simon, Minimalism and Experimentalism in the Administrative State, 100 GEO. L.J. 53, 54 (2011). For a summary and critique of regulatory reform models prevailing throughout the last few decades, see Jodi L. Short, The Paranoid Style in Regulatory Reform, 63 HASTINGS L.J. 633, 634 (2012).

2. For a sweeping review of the concepts and history of market-based regulation, see Moving to Markets In ENVIRONMENTAL REGUlation 3 (Jody Freeman \& Charles D. Kolstad eds., 2007) [hereinafter MOVING TO MARKETS].

3. For the seminal description of adaptive management, see INT'L INST. FOR APPLIED SYS. ANAlysis, AdAPTIVE ENVIRONMENTAL ASSESSMENT AND MANAgEMENT 1 (C.S. Holling ed., 1978). For a more recent synthesis of adaptive management theory, see PANARCHY: UNDERSTANDING Transformations in Human AND NATURAL Systems 3 (Lance H. Gunderson \& C.S. Holling eds., 2002). See generally infra Part I.A (tracing the history of adaptive management).

4. Minimalism "seeks to ground policy design in economic concepts and market practices, and to minimize frontline administrative discretion and popular participation in administration." Sabel \& Simon, supra note 1, at 54-55. 
"experimentalism,"5 market-based regulation and adaptive management originate from the same premise but move in starkly different directions. This Article examines the path that adaptive management has taken and proposes how to steer it out of a dead end by changing the inner workings of administrative law.

The starting point for both regulatory reform models is the depiction of administrative agencies as having become boxed into a decisionmaking process that depends heavily on a culture of comprehensive rational planning and prescriptive regulation. ${ }^{6}$ The dominant decisionmaking method used to implement this regime relies heavily on two related attributes: (1) the use of "front-end" analytical tools comprehensively conducted and concluded prior to finalizing the decision, and (2) the assumption of a robust capacity to predict and assess the market and nonmarket impacts of any proposed action. ${ }^{7}$ However, this approach constrains agency flexibility by demanding hyperdetailed predecisional impact assessments, intense public participation during the decisionmaking process, and postdecision hard look judicial review. ${ }^{8}$ The combined effect of this procedural gauntlet, codified in large part through the federal Administrative Procedure Act

5. Experimentalism's "governing norm in institutional design is reliability - the capacity for learning and adaptation." Id. at 55.

6. See J.B. Ruhl \& Robert L. Fischman, Adaptive Management in the Courts, 95 MinN. L. REV. 424, 437 (2010) (discussing the central attributes of the modern agency-decisionmaking process).

7. For example, regulations promulgated under the Endangered Species Act require federal agencies, prior to carrying out, funding, or authorizing an action, to "[e]valuate the effects of the action and cumulative effects" and decide "whether the action, taken together with cumulative effects, is likely to jeopardize the continued existence of listed species." 50 C.F.R. § 402.14(g)(3)(4) (2009). Cumulative effects are "those effects of future State or private activities, not involving Federal activities, that are reasonably certain to occur within the action area." Id. $\S 402.02$. In other words, the agency must decide, once and for all, whether an action taken today will jeopardize a species at some point in the future. The agency may revisit its decision only if the action remains subject to continuing federal control and either new information or modifications of the action present effects that were not previously considered. See id. § 402.16 (discussing when reinitiation of formal consultation is required).

8. Professors Sidney Shapiro and Robert Glicksman have produced a rich body of scholarship exploring the conventional "front-end" approach to agency decisionmaking. See SIDNEY A. SHAPIRO \& RobERT L. GLICKSMAn, Risk REgulation AT Risk, at x (2003) (suggesting that pragmatism, rather than utilitarianism, is the "appropriate baseline from which to design and implement risk regulation"); Robert L. Glicksman \& Sidney A. Shapiro, Improving Regulation Through Incremental Adjustment, 52 U. KAN. L. REV. 1179, 1179 (2004) (advocating a shift in focus from "front-end" regulatory adjustment to "back-end" regulatory improvements, including use of adaptive management); Sidney A. Shapiro \& Robert L. Glicksman, The Missing Perspective, ENVTL. L.F., Mar.-Apr. 2003, at 42, 42 ("Instead of the increased 'front end' examination of regulations, such as cost-benefits analysis, that is pushed by the critics-and is causing stagnation of rulemaking - a pragmatic approach would look at a regulation's actual 'back end' effects after promulgation and make incremental adjustments as needed."). 
(“APA") ${ }^{9}$ and its state counterparts, has been to channel self-preserving agencies into cramming all that could possibly be thought or dreamed about actions they carry out, fund, or authorize into single-shot, allencompassing decision extravaganzas. Especially in rulemaking, this impetus toward up-front comprehensiveness strongly encourages agencies to steamroll their decisions through public-comment scrutiny and judicial review litigation and then never look back. ${ }^{10}$ Reopening or reconsidering a completed and judicially blessed decision in such an environment is anathema to any sane agency.

To be sure, even under the pressure of these external "rationalinstrumental" constraints on agency discretion, ${ }^{11}$ the front-end mode of administrative decisionmaking does produce agency decisions sooner or later, even decisions of momentous import and magnitude. However, it cannot be denied that this mode of agency decisionmaking has also been subjected to withering criticisms that it ossifies agency practices, politicizes agency decisions, stultifies flexibility, and generally makes administrative agencies unadministrative. ${ }^{12}$

9. 5 U.S.C. $\$ \S 551-59,701-06$ (2012).

10. See J.B. Ruhl, Regulation by Adaptive Management-Is It Possible?, 7 MinN. J.L. SCI. \& TECH. 21, 34-53 (2005) (noting that most administrative agencies are increasingly required to engage in predecisional activity geared towards public participation and judicial review before promulgating a rule or adjudicating a decision).

11. Sidney Shapiro et al., The Enlightenment of Administrative Law: Looking Inside the Agency for Legitimacy, 47 WAKE FOREST L. REV. 463, 464-65 (2012) (critiquing the "rationalinstrumental" model of administrative decisionmaking and proposing a "deliberative-constitutive" model based in more iterative, discursive use of professional agency judgment); see also William Simon, The Organizational Premises of Administrative Law, 76 LAW \& CONTEMP. PRoBs. (forthcoming) (manuscript at 5), available at http://ssrn.com/abstract=2332079 (providing an overview of "the most dysfunctional features of canonical [administrative law] doctrine - both the excessively burdensome ones and the excessively lax ones" and contending that they all derive from a "highly limited and increasingly anachronistic conception of public administration.")

12. See William S. Jordan, III, Ossification Revisited: Does Arbitrary and Capricious Review Significantly Interfere with Agency Ability to Achieve Regulatory Goals Through Informal Rulemaking?, 94 Nw. U. L. REV. 393, 393-95 (2000) (pointing out criticisms that hard look review has ossified the informal rulemaking process); Thomas O. McGarity, Administrative Law as Blood Sport: Policy Erosion in a Highly Partisan Age, 61 DukE L.J. 1671, 1671 (2011) (noting that "regulated industries, and occasionally beneficiary groups, are willing to spend millions of dollars to shape public opinion and influence powerful political actors to exert political pressure on agencies"); Thomas O. McGarity, Some Thoughts on "Deossifying" the Rulemaking Process, 41 DUKE L.J. 1385, 1385 (1992) (noting that the informal rulemaking process has become increasingly "rigid and burdensome"); Edward Rubin, It's Time to Make the Administrative Procedure Act Administrative, 89 CORNELl L. REV. 95, 100-45 (2004) (providing a broad critique of the public participation-judicial review model of administrative law); Mark Seidenfeld, Demystifying Deossification: Rethinking Recent Proposals to Modify Judicial Review of Notice and Comment Rulemaking, 75 TEX. L. REV. 483, 483-89 (1997) (discussing criticisms that the informal rulemaking process has become "unnecessarily cumbersome"). 
Market-based regulation, a darling of minimalism theory, responds to these criticisms by replacing some measure of agency discretion with the dynamic organizing power of markets and economic incentives. ${ }^{13}$ The job of agencies in this approach is to set up the framework in which market forces can operate and then sit back and watch the elegance of economic incentives drive market-participant behavior in the desired direction. ${ }^{14}$ In environmental regulation, for example, so-called pollution cap-and-trade systems have the agency prescribe aggregate, industry-wide pollution loads; allocate initial pollution units to industry participants; and set up the rules for trading those units; from there, however, the market defines the unit price and drives trading behavior. ${ }^{15}$ Similarly, conservation-banking programs allow one landowner to destroy natural resources, such as wetlands or endangered species' habitat, and offset the lost ecological values by purchasing resource credits in an open market from another landowner who has created or enhanced similar resources. ${ }^{16}$ The point of such programs is specifically to remove agency discretion from decisions about trading partners, prices of credits, and other features taken over by the regulatory market, the theory being that the market can perform those functions more efficiently and effectively than can agency expertise and intervention. ${ }^{17}$ Indeed, with the agency removed from the picture, at least partially, the market-directed portion of the process also effectively supplants public participation and judicial review-the market $i s$ the public, and the market does not get it wrong, so judicial review is unnecessary. At least, that's the theory of market-based regulation.

13. See Sabel \& Simon, supra note 1, at 57 (noting that "minimalists look to economics for norms and practices that obviate official discretion").

14. Notably, even as far back as 1975, legal scholars considered the elimination of administrative agencies and a return to the pure market as a possible solution to increasing agency discretion. Richard B. Stewart, The Reformation of American Administrative Law, 88 HARV. L. REV. 1667, 1689-93 (1975).

15. See A. Denny Ellerman, Are Cap-and-Trade Programs More Environmentally Effective than Conventional Regulation?, in MOVING TO MARKETS, supra note 2, at 48 (comparing cap-andtrade to prescriptive regulation); Karen Fisher-Vanden \& Sheila Olmstead, Moving Pollution Trading from Air to Water: Potential, Problems, and Prognosis, 27 J. ECON. PERSP. 147, 148 (2013) (examining air- and water-pollutant trading programs).

16. See James Salzman \& J.B. Ruhl, "No Net Loss": Instrument Choice in Wetlands Protection, in MOVING TO MARKETS, supra note 2, at 323 (describing wetlands banking).

17. See Jody Freeman \& Charles D. Kolstad, Prescriptive Environmental Regulations Versus Market-Based Incentives, in MOVING TO MARKETS, supra note 2, at 3 (market-based theorists posit that "[n]ot only would market instruments be easier and cheaper to administer than prescriptive regulation, they would harness the profit motive in the service of environmental protection and dramatically reduce implementation costs"). 
Championing experimentalism, adaptive management offers a much different path away from the conventional front-end model of decisionmaking. The key move is not to carve away agency discretion, as market-based regulation does, but to add to it, albeit in a vastly different form compared to the front-end model. ${ }^{18}$ The idea of adaptive management is that agencies should be free to make more decisions, but that the timing of those decisions is spread out into a continuous process that makes differentiating between the "front end" and the "back end" of decisionmaking much less relevant. ${ }^{19}$ Rather than make one grand decision and move on, agencies employing adaptive management engage in a program of iterative decisionmaking following a structured, multistep protocol: (1) definition of the problem, (2) determination of goals and objectives for management, determination of the baseline, (4) development of conceptual models, (5) selection of future actions, (6) implementation and management actions, (7) monitoring, and (8) evaluation and return to step (1). ${ }^{20}$ Formal, time-limited public participation junctures, such as the noticeand-comment process of conventional APA-style administrative rulemaking, are not a component of adaptive management; rather, public input is derived through an emphasis on more loosely defined processes for "stakeholder involvement" and multiparty "collaborative planning." 21 With deep roots in natural resources

18. See Sabel \& Simon, supra note 1, at 78 (explaining that experimentalism involves discretion distributed through a more decentralized structure but with centralized coordination); see also Lawrence E. Susskind \& Joshua Secunda, "Improving” Project XL: Helping Adaptive Management to Work Within EPA, 17 UCLA J. ENVTL. L. \& POL'Y 155, 166-67 (1999) (arguing that legislatively allowed adaptive management would increase agency discretion as compared to conventional administrative regimes).

19. See Lawrence Susskind et al., A Critical Assessment of Collaborative Adaptive Management in Practice, 49 J. APPLIED ECOLOGY 47, 47 (2012) ("Rather than making a single definitive decision despite information gaps or uncertainty about the systems involved, [adaptive management] emphasizes learning via the careful monitoring of provisional strategies and changing conditions, and incremental adjustments in light of new information.”).

20. See Comm. on Endangered \& Threatened Fishes in the Klamath River Basin, Endangered AND Threatened Fishes IN the KLAMATh River BAsin 332-35 (2004) (explaining the adaptive management decisionmaking process). Adaptive management theorists propose many configurations of the iterative steps. See infra Part II.A. This protocol is taken from work by the National Research Council's work on endangered species issues in the Klamath River basin in the Pacific Northwest. In the interests of full disclosure, Professor Ruhl served on the so-called "Klamath Committee," including its work on defining and applying adaptive management.

21. See Cal. Envtl. Prot. Agency, Air Res. Bd., Adaptive Management Plan for the CAP-AND-TRADE REGULATION 1-2 (2011), available at www.arb.ca.gov/cc/capandtrade/adaptive_ management/plan.pdf (presenting an adaptive management plan for implementation of an air pollutant trading program); see also Susskind et al., supra note 19, at 49-50 (stressing the importance of "collaborative planning" in adaptive management); Byron K. Williams, Adaptive Management of Natural Resources-Framework and Issues, 92 J. ENVTL. MGMT. 1346, 1348 (2011) 
management theory, ${ }^{22}$ the adaptive management protocol has begun to make inroads in public lands management in particular, ${ }^{23}$ though it has been applied or proposed in other policy contexts, including pollution control, ${ }^{24}$ financial regulation, ${ }^{25}$ environmental impact assessment, ${ }^{26}$ public health and safety, ${ }^{27}$ civil rights, ${ }^{28}$ and social welfare ${ }^{29}$

Market-based regulation and adaptive management have by no means taken over the administrative state. Rather, they have been used more opportunistically than holistically, stepping in strategically where conventional front-end decisionmaking has failed or needs help. Indeed, they have been used that way in unison in some cases. For example, when the Endangered Species Act ("ESA") came under heated attack in the mid-1990s as too blunt a regulatory tool, its implementing agencies used carefully targeted doses of market-based regulation and adaptive management to make the regulatory programs more nuanced and

(identifying "stakeholder involvement" as "[a] key step in any adaptive management application"). For elaboration on what these are, see infra Part II.A.

22. See Holly Doremus et Al., Ctr. For Progressive Reform, Making Good Use of ADAPTIVE MANAGEMENT 3 (2011) ("Since the mid-1990s, the concept of adaptive management has held a prominent place in natural resource management policy in the United States ...."). For the seminal works linking adaptive management with natural resources management policy, see Norman L. Christensen et al., The Report of the Ecological Society of America on the Scientific Basis for Ecosystem Management, 6 ECOLOGICAL ApPLiCATIONs 665, 666 (1996), and R. Edward Grumbine, What is Ecosystem Management?, 8 Conservation Biology 27, 29-31 (1994).

23. See Jamie McFadden et al., Evaluating the Efficacy of Adaptive Management Approaches: Is There a Formula for Success?, 92 J. ENVTL. MGMT. 1354, 1357-58 (2011) (showing a sharp upward trend of discussion of adaptive management in major natural resources management journals since 2000); Susskind et al., supra note 19, at 47 ("Collaborative adaptive management (CAM) is widely touted as the best way to handle natural resource management in the face of uncertainty, change and conflict.”).

24. See Susskind \& Secunda, supra note 18, at 169 (discussing an innovative pollution-control program and reporting that the program was supported by the fact that "important constituencies within all [stakeholder] groups understand that adaptive management holds great promise for the improvement of environmental compliance regimes").

25. See Charles K. Whitehead, The Goldilocks Approach: Financial Risk and Staged Regulation, 97 CORNELL L. REV. 1267, 1302-04 (2012) (proposing an iterative regulatory regime for financial institutions).

26. See Julie Thrower, Adaptive Management and NEPA: How a Nonequilibrium View of Ecosystems Mandates Flexible Regulation, 33 ECOLOGY L.Q. 871, 894 (2006) (discussing the integration of adaptive management principles in predecisional environmental-impact assessments).

27. See William H. Simon, Democracy and Organization: The Further Reformation of American Administrative Law 35-41 (Columbia Law Sch. Pub. Law \& Legal Theory Working Paper Grp., Paper No. 12-322, 2012) (discussing the Workforce Investment Act of 1998).

28. See id. (discussing the Prison Rape Elimination Act of 2003).

29. See id. (discussing the Food Safety Modernization Act of 2011). 
flexible at the edges. ${ }^{30}$ Although still dominated by front-end decisions about the status of species for protection and the conditions under which federal and nonfederal actions can take place in habitats of protected species, the regulatory program has evolved considerablyand the statute has survived the political assaults-thanks largely to the administrative reforms. ${ }^{31}$

As between the two approaches, market-based regulation has a much longer and more tested track record than does adaptive management, although the jury is still out on its performance in numerous applied settings. ${ }^{32}$ Concerns with market-based approaches include, for example, whether pollution trading allows "hot spots" of intense local pollution to form ${ }^{33}$ and whether agencies can balance the goals of the statute with the administrative goal of maintaining a viable trading market. ${ }^{34}$ In general, however, most of these concerns can (in theory) be addressed through further tinkering with the regulatorymarket frameworks. That is to say, the basic theory of market-based regulation is firmly in place, and the principles for its design and application in the field are by now well understood, even if not always effectively executed. ${ }^{35}$

By contrast, the adaptive management trial has only recently begun, and it is moving slowly and with mixed results. Putting adaptive management into practice has proven far more difficult than its early theorists expected. ${ }^{36}$ One problem has been translating the theory into

30. See J.B. Ruhl, Who Needs Congress? An Agenda for Administrative Reform of the Endangered Species Act, 6 N.Y.U. ENVTL. L.J. 367, 374-400 (1998) (contemporaneously examining the Babbitt-era reforms).

31. See J.B. Ruhl, Endangered Species Act Innovations in the Post-Babbittonian Era-Are There Any?, 14 DukE ENVTL. L. \& POL'Y F. 419, 430-38 (2004) (reflecting on the Babbitt-era reforms).

32. See Freeman \& Kolstad, supra note 17, at 3-15 (providing a comprehensive assessment of the first twenty years of applied market-based regulation in the environmental policy context); Lawrence Goulder, Markets for Pollution Allowances: What Are the (New) Lessons?, 27 J. ECON. PERSP. 87, 87-88 (2013) (tracing "cap-and-trade" theory to the 1960s and its policy applications from the 1970s forward).

33. See Ellerman, supra note 15, at 51-52 (examining the "hot spots" issue).

34. See Salzman \& Ruhl, supra note 16, at 335-39 (examining the difficulties of maintaining regulatory markets).

35. See Fisher-Vanden \& Olmstead, supra note 15, 157-64 (defining criteria for successful pollutant-trading programs); Goulder, supra note 32, at 100 (stating that cap-and-trade and pollution taxes, "[w]hen well designed, either form of emissions pricing will offer several advantages over conventional forms of regulation").

36. See Craig R. Allen et al., Adaptive Management for a Turbulent Future, 92 J. ENVTL. MGMT. 1339, 1341 (2011) (noting that "despite an illustrious theoretical history there has remained imperfect realization of adaptive management in [the] real world"); Craig R. Allen \& Lance H. Gunderson, Pathology and Failure in the Design and Implementation of Adaptive 
the legal context of agency practice. It is easy for politicians to command agencies to "go practice adaptive management" and leave it to others to figure out how. ${ }^{37}$ Agencies working in good faith to follow through on the promise of adaptive management, however, have found themselves facing a public suspicious of seemingly unbounded agency discretion ${ }^{38}$ and courts unaccustomed to the "dial twiddling" of adaptive management's decisionmaking protocol. ${ }^{39}$ Agencies thus are caught between a rock and a hard place-they must implement adaptive management to keep in step with dominant management decision theory, but when they do, they face a tough audience in the public and judicial forums.

The result has been agencies perfecting and practicing what has been dubbed "a/m lite," a watered-down form of adaptive management agencies use to play it safe. ${ }^{40}$ The first step in an agency's descent into

Management, 92 J. EnVTL. MGMT. 1379, 1380 (2011) ("The implementation of adaptive management has proven to be difficult."); Holly Doremus, Adaptive Management, the Endangered Species Act, and the Institutional Challenges of "New Age" Environmental Protection, 41 WASHBURN L.J. 50, 54 (2001) (noting that "skepticism about adaptive management comes from the lack of success stories to date"); McFadden et al., supra note 23, at 1358 ("While managers in the field of natural-resources generally acknowledge adaptive management as an appropriate approach for managing complex ecosystems, the managers may experience difficulty in proceeding with the adaptive management process to the implementation stage.”); Susskind et al., supra note 19, at 47 ("[T]he results have been mixed, with many efforts falling short of the resource management results that were expected."); Carl J. Walters, Is Adaptive Management Helping to Solve Fisheries Problems?, 36 AMBIO 304, 304 (2007) (arguing that adaptive management has "been radically less successful than one would expect from its intuitive appeal").

37. See, e.g., Exec. Order No. 13,508, 74 Fed. Reg. 23,099, 23,101-03 (May 12, 2009) (directing the EPA to draft pollution-control strategies for the Chesapeake Bay watershed that are "based on sound science and reflect adaptive management principles," while also directing the Departments of the Interior and Commerce to use "adaptive management to plan, monitor, evaluate, and adjust environmental management actions" in the Chesapeake Bay watershed, but not defining any of these concepts). Alejandro Camacho has outlined the core substantive features of an "adaptive governance framework as part of organic adaptation planning legislation." Alejandro E. Camacho, Adapting Governance to Climate Change: Managing Uncertainty Through a Learning Infrastructure, 59 EMORY L.J. 1, 72-76 (2009). Our focus in this Article is on the procedural features.

38. DOREMUS ET AL., supra note 22, at 3 ("[E]nvironmentalists argue that adaptive management places too much open-ended discretion in the hands of agency managers."); Melinda Harm Benson \& Ahjond S. Garmestani, Embracing Panarchy, Building Resilience and Integrating Adaptive Management through a Rebirth of the National Environmental Policy Act, 92 J. ENVTL. MGMT. 1420, 1422 (2011) ("[C]ritics of adaptive management view it as an excuse to allow agencies an unreasonable amount of discretion .....”; Courtny Schultz \& Martin Nie, Decision-making Triggers, Adaptive Management, and Natural Resources Law and Planning, 52 NAT. ResourCES J. 443, 449-51 (2012) (discussing why the "discretion-based approach to adaptive management did not sit well with environmental groups").

39. See Ruhl \& Fischman, supra note 6, at 439-40 (describing adaptive management as "dial twiddling" and analyzing the poor reception it has received in courts).

40. See id. at 431-43 (describing agencies' practice of a/m lite). 
$\mathrm{a} / \mathrm{m}$ lite is to dilute the definition of adaptive management into a longwinded abstraction of "learning while doing." 41 From there, the agency can pepper its rules, permits, and policies with promises to employ adaptive management while making no firm commitments to do anything in particular. ${ }^{42}$ At its best, therefore, a/m lite simply supplements agencies' front-end decisions with bold promises to adapt unspecified parameters of the decision in the unspecified future through unspecified methods when unspecified conditions arise. ${ }^{43}$ At its worst, $\mathrm{a} / \mathrm{m}$ lite allows agencies to defer hard decisions indefinitely by shifting them into the adaptive management black box. ${ }^{44}$ Like many plans, an adaptive management plan of $\mathrm{a} / \mathrm{m}$ lite origin is more likely to find itself sitting on the shelf than springing into action.

This false start in adaptive management practice has led some commentators to ask whether implementing adaptive management consistent with its full theoretic model is truly possible for regulatory agencies, or whether the whole idea will be ground to pieces by the administrative state's demands for comprehensive predecisional impact assessments, relentless public participation, and routine access to probing judicial review. ${ }^{45}$ If agencies are committed to adaptive

41. For example, the Department of the Interior defines adaptive management as a decisionmaking process that

promotes flexible decision making that can be adjusted in the face of uncertainties as outcomes from management actions and other events become better understood. Careful monitoring of these outcomes both advances scientific understanding and helps adjust policies or operations as part of an iterative learning process . . . It is not a 'trial and error' process, but rather emphasizes learning while doing.

Byron K. Williams et AL., AdAPtive Management: The U.S. Department of Interior TEChNiCAL GUIDE, at v (2009). For similar examples, see Ruhl \& Fischman, supra note 6, at 43133.

42. For example, rules the Army Corps of Engineers has adopted to implement the Clean Water Act's wetland compensatory mitigation program require permit applicants to develop an "adaptive management plan" to "guide decisions for revising compensatory mitigation plans and implementing measures to address both foreseeable and unforeseen circumstances that adversely affect compensatory mitigation success.” 33 C.F.R. § 332.4(c)(12) (2013). Yet the rules do not go further in explaining how these plans are to be implemented, leaving it to the local Army Corps "district engineer, in consultation with the responsible party (and other federal, tribal, state, and local agencies, as appropriate), [to] determine the appropriate measures." Id. § 332.7(c)(3). The upshot of the rule is that the adaptive management plan will be used when deemed necessary, at which time the district engineer, permittee, and other interested parties will figure out how to adapt. For similar examples, see Ruhl \& Fischman, supra note 6, at 433-36.

43. See DoremUS ET AL., supra note 22, at 11 ("One of the most significant weaknesses of adaptive management to date has been that agencies have promised future adaptation but not delivered it.").

44. See id. at 3 (stating that adaptive management is "at worst a smokescreen for unbounded agency discretion and a wobbly commitment to program objectives").

45. Craig Allen and his colleagues have noted, for example, that: 
management but unable as a practical matter to move it past $\mathrm{a} / \mathrm{m}$ lite, one has to wonder whether these core features of conventional administrative law-the features that incentivize front-end decisionmaking - aren't in fact the problem that needs to give ground. The bottom line may be that either we can leave administrative law untouched, in which case $\mathrm{a} / \mathrm{m}$ lite is about as far as adaptive management will progress, or we can design an alternative administrative procedure model that enables agencies to practice adaptive management in its purer form. Indeed, a recent survey of adaptive management practitioners revealed that most of them believe implementation of adaptive management has reached this crossroads. ${ }^{46}$

Before casting stones on administrative law as the barrier to moving beyond $\mathrm{a} / \mathrm{m}$ lite, though, one must also consider whether adaptive management's acolytes have oversold its virtues and set legal process up for the fall. Other constraints stand in the way of effective

Legal certainty does not mesh well with environmental unpredictability. . . . The certainty of law and institutional rigidity often limit the experimentation that is necessary for adaptive management[,]" and the "adversarial character of administrative law, combined with the need for certainty (e.g., procedural rules) in the larger realm of American law, is likely incompatible with adaptive management.

Allen et al., supra note 36, at 1343 (citations omitted). Professor Angelo adds:

Another challenge of adaptive management is that it may be difficult to incorporate substantial public participation. ... If we need to wait to convene all stakeholders and achieve consensus or near consensus before every action, we simply will not be able to have the quick reaction time necessary for adaptive management.

Mary Jane Angelo, Stumbling Toward Success: A Story of Adaptive Law and Ecological Resilience, 87 NEB. L. REV. 950, 1001-02 (2009). Finally, Professor Karkkainen has argued that:

[T] he adversarial and litigious character of contemporary administrative law coupled with its overall tendency toward nitpicking enforcement of fixed 'command-and-control' rules-especially procedural rules, which are singularly easy for courts to enforce-and its reluctance to countenance uncertainty and lack of information as the basis for agency decisionmaking are all profoundly at odds with the very concept of adaptive management.

Bradley C. Karkkainen, Panarchy and Adaptive Change: Around the Loop and Back Again, 7 MinN. J.L. SCI. \& TECH. 59, 73 (2005); see also Ruhl, supra note 10, at 34-36 (identifying disconnects between adaptive management and conventional administrative procedure); Brian Walker et al., Resilience, Adaptability and Transformability in Social-Ecological Systems, 9 ECOLOGY \& SOC'Y, no. 2, 2004, at art. 5 (citations omitted), available at http://www.ecology andsociety.org/vol9/iss2/art5/ ("Adaptive management, widely and deservedly promoted as a necessary basis for sustainable development, has frequently failed because the existing governance structures have not allowed it to function effectively.").

46. Professors Benson and Stone report that practitioners do feel hampered by legal and institutional constraints. See Melinda Harm Benson \& Asako Stone, Practitioner Perceptions of Adaptive Management Implementation in the United States, 18 ECOLOGY \& Soc'Y, no. 3, 2013, at art. 32, available at http://www.ecologyandsociety.org/vol18/iss3/art32/ (finding well over seventy percent not only believed that constraints exist and could specifically name one or more example of a legal constraint on their work implementing adaptive management; at the same time, finding "practitioners are generally optimistic about the potential for institutional reform"). 
administrative agency adaptive management, not the least of which are funding, politics, uncertainty, data scarcity, and lack of institutional capacity. ${ }^{47}$ Working to get past $\mathrm{a} / \mathrm{m}$ lite in some contexts thus may be asking the agency to hit its head against a wall. Even in the best of such circumstances, moreover, adaptive management also may not be suited to regulatory contexts (1) in which long-term stability of decisions is important, such as child labor controls; (2) where decisions simply can't easily be adjusted once implemented, such as where to locate a completed highway intersection; or (3) where it is essential that an agency retain firm authority to say "yes" or "no" and leave it at that. Hurling the words "adaptive management" at a regulatory problem thus asks for failure if either the nature of the problem or its practical context is not well suited for adaptive decisionmaking.

We recognize these limitations on adaptive management and thus the need for reformers first to sort through the rhetoric of adaptive management to define where it could truly be usefully and practicably implemented. Only then can one evaluate how much of a barrier conventional administrative law poses to doing so. If adaptive management is promising in some decisionmaking contexts, however, and administrative law the principal obstacle to fulfilling that promise, then it is appropriate to ask what an alternative administrative process would have to look like to unleash adaptive management's potential. How far would the alternative need to deviate from conventional administrative law, and would there be unacceptable tradeoffs with other values administrative law serves to fulfill? An informed deliberation on the practice of adaptive management in the administrative state must address these questions-in short, to ask whether it is administrative law, not the pursuit of adaptive management, that is maladaptive, and if so, what to do. ${ }^{48}$ Yet, while there is broad agreement among adaptive management theorists on the first point-administrative law has become a barrier to effective

47. See Eric Biber, Adaptive Management and the Future of Environmental Law, 46 AKRON L. REV. (forthcoming 2013) (manuscript on file with author) (identifying numerous barriers to adaptive management besides administrative law); Alejandro E. Camacho, Can Regulation Evolve? Lessons from a Study in Maladaptive Management, 55 UCLA L. REV. 293, 297-98 (2007) (critiquing the use of adaptive management in the Endangered Species Act); Doremus, supra note 36, at 50-52 (identifying challenges for adaptive management in the administration of the Endangered Species Act); Annecoos Wiersema, A Train Without Tracks: Rethinking the Place of Law and Goals in Environmental and Natural Resources Law, 38 ENVTL. L. 1239, 1239 (2008) (arguing that adaptive management by agencies pays insufficient attention to substantive goals).

48. As Brad Karkkainen has put it, to consider adaptive management seriously, one must suspend the premise that "administrative law w[as] somehow immutable and eternal, or at least of constitutional stature, rather than just another statutory and judge-made legal artifact that may prove maladaptive at some point." See Karkkainen, supra note 45, at 69 . 
adaptive management-what to do about it has not received focused attention.

This Article represents the first effort in adaptive management theory to go beyond complaining about the handcuffs imposed by administrative law and suggest a solution. Theorists (including us) have proposed the idea of a specialized procedural "track" for adaptive management, ${ }^{49}$ but the devil is in the details. Here, we propose the details. To initiate that inquiry, Part II of this Article grounds the theory of adaptive management in the real world conditions under which its pure practice is most likely to be of value. Having identified those conditions, Part III then focuses on the values of conventional administrative law and the obstacles they pose for agency implementation of true adaptive management. Using our proposed Model Adaptive Management Procedure Act ("MAMPA") as the analytical foundation, Part IV closes by working through the provisions of a new administrative law track for adaptive management that balances those values with the values and practical needs of adaptive management.

Before going into details, however, some caveats are in order. First, our proposed adaptive management track is simply an alternative set of administrative procedures to those found in the current APA and its state counterparts, designed to facilitate agency implementation of proper adaptive management in appropriate (not all) regulatory contexts. We do not propose far-ranging fixes to more general administrative law problems, such as agency recalcitrance in implementing statutory mandates or abuse of agency discretion, even though we admit from the outset that they are theoretically at least as likely to occur on the adaptive management track as in any other administrative law context. Nevertheless, because the adaptive management track accords a participating agency more ongoing discretion than typical front-end agency decisionmaking, we purposely have designed our adaptive management track so that an agency's decision to take it must be considered, deliberate, and-to the extent that procedural constraints can so guarantee-committed to following in good faith proper adaptive management procedures.

49. See, e.g., id. at 75 ("One might envision administrative law proceeding on two tracks[,]" one being a "familiar 'fixed rule' track" and the other an "adaptive management track."); see also Robin Kundis Craig, "Stationarity is Dead"-Long Live Transformation: Five Principles for Climate Change Adaptation Law, 34 HARV. EnVTL. L. REV. 9, 17, 66-67 (2010) (suggesting the need to "restructure those legal safeguards and allow administrative agencies more breathing room"); J.B. Ruhl, A Manifesto for the Radical Middle, 38 IDAHO L. REV. 385, 406-07 (2002) (calling for greater discretion and more deferential and reduced judicial review for agencies involved in adaptive management). 
Second, we propose general procedures-like those in the APAthat should be able to govern a wide variety of agency types (financial and business, health and public safety, environmental, consumer protection, etc.) in a wide variety of regulatory contexts. Nevertheless, we acknowledge that the relevant legislature might want to tailor these procedures for particular agencies or regulatory contexts, as is true in current administrative law. For example, a legislature may deem desirable recurrent peer review of how an agency implements adaptive management for certain agencies or for longer-term projects. Our proposal is not intended to short-circuit such legislative tailoring any more than the APA stymies Congress in adding procedural modifications to particular statutes; rather, like the APA, our proposed statute provides a general procedural template that legislatures remain free to tweak as they deem appropriate for particular agencies or areas of law.

Finally, other than identifying the general context within which adaptive management is likely to be effective, we confine our analysis to the administrative procedure of adaptive management. We do not suggest with any specificity where and when adaptive management should be used as a matter of policy, nor do we outline how a legislature might craft a statute conferring substantive authority to an agency to practice adaptive management. The APA has more than adequately demonstrated that procedure matters; hence, we believe defining the procedure of adaptive management is as important as defining its substance.

Our singular focus is, in other words, on process. Adaptive management is a structured decisionmaking process in need of a structured legal process. All adaptive management theorists and practitioners, and all administrative procedure theorists and practitioners, have a stake in the project of designing administrative law for adaptive management. To be sure, adaptive management is not a panacea for the administrative state, yet it is difficult to conceive how regulation can function effectively in the future without making true adaptive management available to agencies in contexts where it is likely to be useful. The mediums of regulation-technology, the environment, public health, financial markets, and so on-are themselves highly adaptive and dynamic. Moreover, forces on the horizon, such as climate change and increasing globalization, will further destabilize regulatory contexts.

The question thus is not whether regulation should be adaptive, but rather where and how to make it so. Early indications from the adaptive management project are that some of its chief obstacles are the entrenched features of conventional administrative law. To move 
adaptive management forward in its appropriate applications, therefore, we must revisit administrative law-we must craft an administrative law for adaptive management. This Article is intended to invigorate an active dialogue for that purpose.

\section{THE THEORY AND LIMITS OF ADAPTIVE MANAGEMENT IN THE ADMINISTRATIVE STATE}

If you plug "adaptive management" into a web browser, you will find over 800,000 sites to explore, including government publications and websites, academic articles, nongovernmental organizations devoted to adaptive management, and some pretty elaborate diagrams of what adaptive management is supposed to look like in practice. Clearly, the idea has caught on. Nevertheless, even its most fervent advocates do not propose adaptive management as appropriate for all regulatory contexts. Indeed, some proponents express concern that adaptive management is being oversold and thus set up for failure. As one prominent adaptive management theorist has suggested,

[T] he concept of learning by doing is so intuitively appealing that the phrase "adaptive management" has been applied almost indiscriminately, with the result that many projects fail to achieve expected improvements. In many instances, that failure may have less to do with the approach itself than with the inappropriate contexts in which it is applied. ${ }^{50}$

Adaptive management theorists have thus increasingly focused on describing success within a particular set of conditions. From there, practical, political, and normative limits further constrain adaptive management's application. Given our purpose in this Article to formulate procedural rules governing adaptive management, it is important that we draw on this body of work to first clarify the substantive contexts within which the procedures would apply.

\section{A. Successful Adaptive Management in Theory}

The theoretical origins of adaptive management can be traced to business management, experimental science, systems engineering, and industrial ecology. ${ }^{51}$ The defining moment for catalyzing it into a robust model for administrative decisionmaking, however, came with the publication of an influential book from the late 1970s, Adaptive

50. Byron K. Williams \& Eleanor D. Brown, U.S. DeP'T of the Interior, Adaptive MANAGEMENT: THE U.S. DEPARTMENT OF THE INTERIOR APPLICATIONS GUIDE 11 (2012).

51. Allen et al., supra note 36, at 1340 (noting these origins). 
Environmental Assessment and Management. ${ }^{52}$ C.S. Holling, the book's editor, and his fellow researchers found conventional methods for managing natural resources at odds with the emerging model of ecosystems as dynamic systems. They focused on the basic properties of ecological systems to provide the premises of a new assessment and management method. ${ }^{53}$ Under a dynamic model of ecosystems, they concluded, management policy must put a premium on collecting information, establishing measurements of success, monitoring outcomes, using new information to adjust existing approaches, and being willing to change. ${ }^{54}$ The traditional management approach of natural resources policy was "to attack environmental stressors in piecemeal fashion, one at a time," and to parcel decisionmaking "out among a variety of mission-specific agencies and resource-specific management regimes." ${ }^{55}$ The adaptive management framework that Holling et al. and other early theorists outlined was more evolutionary and interdisciplinary, relying on iterative cycles of goal determination, model building, performance-standard setting, outcome monitoring, and standard recalibration. ${ }^{56}$

Since then, adaptive management theory has evolved into two dominant branches. The Decision-Theoretic School stresses working with relevant policy stakeholders to define the management problem, but from there relies principally on agency experts to develop process models used to guide adaptive decisionmaking. ${ }^{57}$ By contrast, the Resilience-Experimentalist School emphasizes maintaining a shared understanding among the relevant policy stakeholders throughout a continuous process of learning, hypothesis testing, and experimentation within the management-problem context. ${ }^{58}$ Both schools, however, stress the formalization of a structured decisionmaking process, ${ }^{59}$ the

52. See AdAPtive ENVIRONMENTAl ASSESSMENT AND MANAGEMENT, supra note 3, at 1; see also Allen et al., supra note 36, at 1340 (recognizing the book as influential and describing Holling, the editor, as "widely recognized as the 'father' of adaptive management"); Kai N. Lee \& Jody Lawrence, Restoration Under the Northwest Power Act: Adaptive Management: Learning from the Columbia River Basin Fish and Wildlife Program, 16 ENVTL. L. 431, 442 n.45 (1986) (tracing the term "adaptive management" to the book).

53. AdAPTIVE ENVIRONMENTAL Assessment AND MANAGEMENT, supra note 3, at 25-37.

54. See id. at 1-16.

55. Bradley C. Karkkainen, Bottlenecks and Baselines: Tackling Information Deficits in Environmental Regulation, 86 TEX. L. REV. 1409, 1439 (2008).

56. See Allen et al., supra note 36, at 1340 (describing the work of another influential early theorist of adaptive management, Carl Walters).

57. See McFadden et al., supra note 23, at 1355 (discussing the attributes of the agencyexpertise model).

58. See id. (discussing the attributes of the active-experimentation model).

59. See id. at 1354-56 (stressing the importance of testing decisionmaking approaches). 
difference between the two being how actively the decisionmakers probe for information and experiment with different policy options within the management-problem context versus relying on modeling and observation. 60 The formal, structured decision process in both cases involves a "setup" phase, during which an agency specifies stakeholder involvement, management objectives, management actions, models, and monitoring plans, followed by an "iterative" phase, during which the agency specifies the decisionmaking process, follow-up monitoring, assessment, and feedback. ${ }^{61}$ It is this structured decisionmaking process that moves adaptive management beyond mere trial and error and contingency planning. ${ }^{62}$

\section{B. Successful Adaptive Management in Practice}

Common to both schools of adaptive management theory are core assumptions about necessary conditions for its successful implementation. ${ }^{63}$ These conditions break down into two broad categories, one having to do with the attributes of the managementproblem context and the other with the practical, political, and normative constraints operating in the decisionmaking environment.

60. Thus the two approaches have been differentiated along the "active" versus "passive" spectrum, with the active end using "a multistep process involving integrative ecological modeling, conscious generation of testable scientific hypotheses, and field experimentation through carefully tailored management interventions designed to test specific hypotheses." Karkkainen, supra note 45, at 70; see also R. Gregory et al., Deconstructing Adaptive Management: Criteria for Applications to Environmental Management, 16 ECOLOGICAL APPLICATIONs 2411, 2412 (2006) (distinguishing between active and passive adaptive management); Byron K. Williams, Passive and Active Adaptive Management: Approaches and an Example, 92 J. ENVTL. MGMT. 1371, 1372-74 (2011) (distinguishing between passive and active adaptive management and providing examples).

61. See Williams \& BRown, supra note 50, at 12-16; Williams, supra note 21, at 1348-50.

62. See Karkkainen, supra note 45, at 72-74; Williams, supra note 21, at 1347.

63. See DOREMUS ET AL., supra note 22, at 5-9; see also, e.g., SEC'Y OF THE INTERIOR, U.S. DEP'T OF THE INTERIOR, ORDER NO. 3270 § 2 (Mar. 9, 2007), available at http://tinyurl.com/order3270:

Consideration of [adaptive management] is warranted when: (a) there are consequential decisions to be made; (b) there is an opportunity to apply learning; (c) the objectives of management are clear; (d) the value of reducing uncertainty is high; (e) uncertainty can be expressed as a set of competing, testable models; and (f) an experimental design and monitoring system can be put in place with a reasonable expectation of reducing uncertainty.

Melinda Harm Benson has fruitfully used these conditions to examine use of adaptive management for energy development on federal public lands. See Melinda Harm Benson, Adaptive Management Approaches by Resource Management Agencies in the United States: Implications for Energy Development in the Interior West, 28 J. ENERGY \& NAT. RESOURCES L. 87, 92-104 (2010). Our synthesis of conditions for successful adaptive management captures each of these concepts and expands on them in several respects based on the work of other adaptive management theorists. 


\section{Management-Problem Context}

Adaptive management theorists, as well as agencies practicing adaptive management, agree that it is not well suited for all regulatory problems. Craig Allen and Lance Gunderson, in their synthesis of the literature on this theme, identify three key characteristics of management problems that define how effective adaptive management can be in application - uncertainty, controllability, and risk ${ }^{64}$ — to which some theorists add a fourth characteristic, dynamic system. ${ }^{65}$ Uncertainty involves the decisionmaker's level of understanding and information regarding the attributes and behavior of the regulatory context in response to its environment as well as to management interventions. ${ }^{66}$ As uncertainty rises, confidence in the front-end decisionmaking method erodes, given its "all in" bet on the agency's big decision. Controllability turns on the degree to which the decisionmaker can manipulate the regulatory environment. ${ }^{67}$ Higher controllability means that decisionmakers have greater capacity to intervene in the management-problem context and thus can engage in more experimentation and option testing. Risk describes the chance that experimentation and other interventions in the management-problem context can lead to irreversible adverse consequences. ${ }^{6}$ Dynamic system, finally, hinges on how static the management-problem context is over time, both inherently and in response to management interventions. ${ }^{69}$ If a regulatory problem is dynamic rather than static, the fundamental question is whether we know enough about the dynamic processes (uncertainty) to manipulate them (controllability) without messing things up (risk).

The sweet spot for using adaptive management is when a management-problem context presents a dynamic system for which uncertainty and controllability are high and risk is low. ${ }^{70}$ For example,

64. See, e.g., Allen \& Gunderson, supra note 36, at 1380, 1383.

65. See, e.g., Williams, supra note 21 , at 1352.

66. See Allen \& Gunderson, supra note 36, at 1380 (describing uncertainty in natural resources management contexts); Williams, supra note 21, at 1347-48 (discussing various sources of uncertainty).

67. See Allen \& Gunderson, supra note 36, at 1379-80 (describing controllability in natural resource management contexts).

68. See id. at 1382-83 (describing risk in natural resource management contexts).

69. See Williams, supra note 21, at 1346 (emphasizing the dynamic nature of contexts appropriate for adaptive management).

70. See Allen \& Gunderson, supra note 36, at 1380, 1383 (comparing different scenarios of uncertainty, controllability, and risk); Holly Doremus, Adaptive Management as an Information Problem, 89 N.C. L. REV. 1455, 1467-70 (discussing the issue of uncertainty), 1477-78 (examining controllability issues) (2011); Williams, supra note 21, at 1346 (noting that "the management 
consider an agency that has been managing a river system with numerous water impoundments over time and is now determining how better to manage the system for ecological values. The river and its associated ecological resources comprise a complex dynamic system subject to change over a spectrum of variables. There may be considerable uncertainty regarding the effects of new management strategies, such as releasing substantially more water from impoundments for extended periods. But there is also considerable control over that decision: the impoundments can be opened or closed at will-and relatively quickly at that. With sufficient monitoring, therefore, risk can likely be kept low by adjusting water releases in response to detected problems before they become more serious.

The main thrust of adaptive management is to reduce uncertainty through integrative learning fostered in a structured, iterative decisionmaking process. This approach is most relevant for dynamic regulatory contexts like this river-management scenario in which uncertainty and controllability are high and risk is low. ${ }^{71} \mathrm{By}$ contrast, if uncertainty is low, investment in learning is unnecessary; if controllability is low, investment in learning is pointless; and if risk is high, investment in intervention could backfire, leading to severe and irreversible consequences. $^{72}$ Therefore, when uncertainty and controllability are low and risk is high, investing in adaptive management would be wasteful or even dangerous. In such situations, the best course would be to build as much resilience as possible into the affected social, economic, or ecological resources and respond reactively to adverse conditions with trial and error. ${ }^{73}$

Recognizing the factors that make adaptive management helpful can, in some regulatory contexts, also suggest that different decisionmaking processes are useful for different aspects of the regulatory problem. Consider, for example, the Food and Drug Administration's ("FDA") approval of new drugs for human use under

situation for adaptive management can be framed in terms of resources that are responsive to management interventions but subject to uncertainties about the impacts of those interventions").

71. See Allen \& Gunderson, supra note 36, at 1380, 1383 (emphasizing these purposes of adaptive management).

72. See id. at 1380-83 (comparing scenarios); Doremus, supra note 70, at 1467 (adaptive management "is only useful if learning is needed").

73. Allen and Gunderson build two matrices, one using uncertainty and controllability as the axes and the other using uncertainty and risk, to allocate different decisionmaking methods to different combinations of these three management-problem context attributes. Allen \& Gunderson, supra note 36 , at 1380,1383 . In addition to adaptive management, the alternative methods they consider are scenario planning, maximum sustained yield, build resilience, best management practice, and nurture and triage. $I d$. 
the federal Food, Drug, and Cosmetic Act. ${ }^{74}$ The whole point of frontend FDA screening is to ensure, to the extent possible from relatively short-term testing, that any new drug is both safe and effective ${ }^{75}$ (i.e., to minimize uncertainty and to minimize the risk before the drug enters the stream of commerce). Such new drug approvals are thus classic "light switch" decisions not amenable to adaptive management. Nevertheless, as approved drugs remain on the market, new risks and uncertainties regarding their safety can emerge-the classic problem of drug-induced toxic torts, as demonstrated by Vioxx and thalidomide. As uncertainty about long-term risks increases but short-term risks remain low, the FDA's control over a drug's continued use remains considerable, suggesting that the FDA could benefit from some sort of adaptive management process to identify, evaluate, and respond to the inevitable longer-term risks. In other words, where uncertainty and controllability are high and risk is low, adaptive management has potential advantages as a decisionmaking method, provided the decisionmaking environment is well suited to its needs.

\section{Decisionmaking Environment}

In addition to describing the ideal conditions of the management-problem context, adaptive management theorists also have outlined a set of practical, political, and normative constraints in the decisionmaking environment that could impede application of adaptive management. ${ }^{76}$ To be sure, alternative decisionmaking methods have their own sets of such constraints, and it is outside the scope of this Article to provide a comparative analysis of the constraints of different methods. Our purpose here is to identify the constraints in the decisionmaking environment that point against using adaptive management in its otherwise appropriate regulatory contexts, unless other viable methods suffer from even more limiting constraints.

First, even in appropriate management-problem contexts, the iterative decisionmaking style of adaptive management must be a good fit for the practical realities of the working environment. ${ }^{77}$ In

74. 21 U.S.C. $\S \S 301-99 d(2012)$.

75. See id. $\S 355(\mathrm{~d})$ (describing the grounds on which the Secretary of Health and Human Services may deny an application for a new drug).

76. For a comprehensive itemization of such constraints in their legal context, see Biber, supra note 47 (manuscript at 6-19) (discussing problems associated with scale, time, cost, politics, information production, institutional continuity, uncertainty, and learning).

77. See Williams \& BRown, supra note 50, at 12 (noting that there must be "a flexible management environment that allows for changes in management as understanding accumulates over time"). 
transportation planning, for example, there is uncertainty regarding the effects of new infrastructure options to address congestion in an urban transit network responding to dynamic demographic and economic trends. ${ }^{78}$ Controllability is high-a new highway or light-rail system can be inserted into the network-and risk of irreversibly massive failure might be assessed as low. Even so, experimenting with highways, light-rail systems, and other large-scale, expensive, and rather permanent infrastructure projects is simply not practical. Transit solutions can be provided incrementally over time, as in phases of a highway project or the addition of a light-rail system to an existing surface road system, but the costs and disruptions of switching them out, testing one mode here and another across town, and deciding midstream with one mode to significantly alter its design all substantially constrain use of adaptive management's iterative decisionmaking process. ${ }^{79}$ Front-end decisionmaking thus dominates transportation planning, ${ }^{80}$ with adaptive management theory applied more to flow-control mechanisms, such as traffic-flow detectors, improved signage, variable tolls, and traffic light timing. ${ }^{81}$

Where iterative decisionmaking is practical given the context, it must have a purpose. An agency charged with adaptive management must also be charged with fulfilling or establishing clear management goals using measurable performance metrics. ${ }^{82}$ Adaptive management isn't just for the kicks of making lots of decisions. In the rivermanagement scenario used above, for example, management goals

78. See Joseph Y.J. Chow et al., A Network Option Portfolio Management Framework for Adaptive Transportation Planning, 45 TRANSP. RES. PART A 765, 765-66 (2011) (discussing the difficulties involved with adaptive transportation planning).

79. See Williams \& BRown, supra note 50, at 12 (noting that "an adaptive approach is not warranted if potential improvements in management are insufficient to justify the costs of obtaining the information needed").

80. See Chow et al., supra note 78, at 765 (arguing that "[c]onventional practice in transportation planning relies on a passive approach to project investment" in which "[e]ach project is typically evaluated in a single long range future forecast year ... without any adaptation to changing conditions over time").

81. See, e.g., Adaptive Traffic Control Systems, PA. DEP'T TRANSP. http://www.dot.state.pa.us/Portal\%20Information/Traffic\%20Signal\%20Portal/adaptivesystems.h tml (last visited Sept. 17, 2013) (providing examples).

82. See Biber, supra note 47 (manuscript at 16-17) (discussing reasons why "clear goals are important for an adaptive management program"); Clinton T. Moore et al., Adaptive Management in the U.S. National Wildlife Refuge System: Science-Management Partnerships for Conservation Delivery, 92 J. ENVTL. MGMT. 1395, 1396 (2011) (noting that adaptive management requires "[a] clear statement of measurable objectives"); Susskind et al., supra note 19, at 50 (concluding from a case study that adaptive management requires "clear goals and concrete objectives against which progress can be measured"); Williams, supra note 21, at 1348-49 (stressing the importance of clearly defined management goals). 
might specify achieving any or a combination of the following: restoring natural conditions, eliminating nonnative species, improving recreational opportunities, protecting endangered species, ensuring continued water supply, and so on. The point is that the agency needs firm outcome targets in order both to design management options, monitoring programs, and assessment methods, and to evaluate alternative management plans.

With goals in hand, the agency must also operate in an environment that allows implementing the core features of adaptive management. There must be technologically feasible methods available for reliably monitoring the relevant system variables. ${ }^{83}$ Some variables, such as rainfall, are easy to monitor; others, such as species population size, may not be. ${ }^{84}$ There must also be a set of management options that are technologically and legally available for the agency to test and compare so as to better inform recurring decisions. ${ }^{85}$ In the rivermanagement scenario, removal of impoundments might be an approach worth considering as a way to improve learning, but the agency might not have the authority to entertain that option, or, as noted above, testing hypotheses about impoundment removal could be very technologically and economically challenging. ${ }^{86}$ Finally, the time frame for monitoring, testing hypotheses, and adjusting management options must match the time frame of the system's dynamic-change properties. ${ }^{87}$ Mismatches can create lags between adaptive management implementation and policy-relevant time frames. If the consequences of a management action cannot be detected for, say, a century, the institutional opportunity to take advantage of adaptive management in realistic policy time horizons is limited. When all of these practical conditions are met, though, the agency is able to work toward the core objective of the adaptive management approachreducing uncertainty about the consequences of adopting available management options while implementing selected options. ${ }^{88}$

Practical suitability for adaptive management, however, does not guarantee political suitability. Adaptive management is a resource-

83. See Doremus, supra note 70, at 1473 (stressing the importance of monitoring).

84. See id. (giving this example).

85. See Moore et al., supra note 82, at 1396 (noting that adaptive management operates through recurrent decisions selecting from "clearly defined decision alternatives").

86. See Doremus, supra note 70, at 1484 (giving this example).

87. See id. at 1472-73 (stressing the importance of matched time frames).

88. See Moore et al., supra note 82, at 1396 (noting that adaptive management "integrates the decision making and learning processes, so that decision making can proceed even as uncertainty is being resolved"). 
intensive decisionmaking method that relies on continuous agency monitoring, experimentation, and assessment. 89 To be sure, the conventional method of front-end decisionmaking burdens agency resources as well, but most of the decisionmaking costs are front loaded. Adaptive management, on the other hand, requires the consistent financial support of legislative funding and agency allocation of funds over extended time frames. This means that legislative and agencylevel leaders-in other words, policymakers-must conclude that reducing uncertainty about the regulatory problem is sufficiently feasible and valuable to justify the costs. ${ }^{90}$ Moreover, political support for adaptive management must persist beyond the initial authorization to practice it-the legislature cannot micromanage or punish agencies' adaptive decisions and expect agencies to break out of the $\mathrm{a} / \mathrm{m}$ lite mold. ${ }^{91}$ Of course, the agency itself also must support a culture of adaptive management. ${ }^{92}$ Adaptive management tolerates the possibility that even with a robustly designed and faithfully implemented adaptive management protocol, some experiments will fail, and some decisions will be proven wrong. If "heads roll" when that happens, agency personnel at the implementation level have little incentive to move beyond $\mathrm{a} / \mathrm{m}$ lite. Finally, most adaptive management theorists include stakeholder engagement as a critical condition for political viability of adaptive management. ${ }^{93}$ Stakeholder engagement allows the agency to learn from the affected community when shaping goals and protocols and to communicate agency decisionmaking

89. See id. at 1396 (noting that adaptive management requires "[a] system of monitoring ... in place to inform the decision maker").

90. See Biber, supra note 47 (manuscript at 8-10) (discussing problems associated with funding and the assessment of whether the costs of adaptive management justify the gains in reducing uncertainty); Camacho, supra note 37, at 72-74 (emphasizing the need for funding to sustain adaptive management monitoring).

91. See Doremus, supra note 70, at 1477-78 ("[I]nitial management steps must not become immediately locked in, either formally by law or informally by reason of their practical effect.").

92. Allen \& Gunderson, supra note 36, at 1382-83 (discussing a number of agency-culture barriers); Susan K. Jacobson et al., Understanding Barriers to Implementation of an Adaptive Land Management Program, 20 Conservation Biology 1516, 1518 (2006) (discussing a number of agency culture barriers); Moore et al., supra note 82, at 1397 (observing that "traditions of the [agency] can make implementation of adaptive management difficult in some settings"); Williams, supra note 21, at 1348 (discussing a number of agency-culture barriers).

93. See Allen \& Gunderson, supra note 36, at 1381 (discussing techniques of stakeholder involvement); Williams, supra note 21, at 1348 (discussing techniques of stakeholder involvement). Even adaptive management's enhanced use of stakeholder engagement confronts potential obstacles in administrative law, however, as the demanding and time-consuming process requirements of the Federal Advisory Committee Act could be triggered. See Melinda Harm Benson, Integrating Adaptive Management and Oil and Gas Developments: Existing Obstacles and Opportunities for Reform, 39 ENVTL. L. REP. 10,962, 10,969-71 (2009) (discussing the potential for the Federal Advisory Committee Act to impede adaptive management). 
assumptions and rationales. To be sure, stakeholder engagement does not necessarily equate with stakeholder support, but lack of engagement is likely to reduce the chances of such support forming.

Even when the management-problem context and decisionmaking environment both point in the direction of using adaptive management, some contexts involve highly normative boundaries that would not allow the degree of experimentation and decision adjustment needed to put adaptive management to work. For example, the "dial twiddling" approach likely would offend sensibilities in contexts such as civil rights and child labor controls. It is outside the scope of this Article to fully inventory what policy realms involve such normative constraints - that is largely a social and political decision. We recognize, however, that these policy realms exist and that, regardless of whether using adaptive management would be practicable in the absence of the normative constraints, it may well be taken off the table as a viable method for decisionmaking.

This is not to say that adaptive management is necessarily inappropriate whenever strong normative principles motivate regulatory policy. Indeed, as suggested above in the ESA context, adaptive management can be embedded within front-end regulatory structures to facilitate overall policy goals. Under the ESA, the designation of a species as endangered is a binary decision that the agency must base solely on the best available science. ${ }^{94}$ No adaptive management is allowed there. Such designation automatically triggers regulatory protection of the species, ${ }^{95}$ but a permitting program allows actions that harm the species to proceed under regulated conditions. ${ }^{96}$ During the 1990s, the ESA-administering agencies reformed that permitting process substantially, including integrating an adaptive management component within the permit program to manage actions that could "pose a significant risk to the species due to significant data or information gaps." 97 In essence, the permit program now involves a traditional front-end decision-whether to issue the permit, and, if so, what should be its initial design-with an iterative decisionmaking

94. 16 U.S.C. $\S 1533(\mathrm{a})(1)$, (b)(1)(A) (2012) (defining the designation criteria).

95. Id. $\S 1538(\mathrm{a})(1)(\mathrm{A})-(\mathrm{B})$ (prohibiting takings of protected species).

96. Id. § 1539(a)(1). Permits under this provision are known as "incidental take permits," but they require applicant submission of a "habitat conservation plan" and thus are also referred to as "HCP permits." Id. § 1539(a)(2)(A).

97. U.S. Fish \& Wildlife Serv., Habitat Conservation Planning Handbook, at add. Executive Summary, at 1 (2000). See generally Notice of Availability of a Final Addendum to the Handbook for Habitat Conservation Planning and Incidental Take Permitting Process, 65 Fed. Reg. 35,242 (June 1, 2000) (providing notice of, and reasons for, the adaptive management revisions). 
component added for long-term management of uncertainty. Although some commentators have accused this program of being more $\mathrm{a} / \mathrm{m}$ lite than true adaptive management, 98 it illustrates the potential for adaptive management to work within a strongly normative and coercive regulatory program rather than as a complete alternative to it.

The ideal policy medium for adaptive management thus exhibits the following set of qualities:

- The management-problem context changes dynamically over time in response to environmental conditions as well as management interventions.

- Decisionmakers have incomplete knowledge of the management-problem context's dynamic processes (uncertainty is high) but can manipulate various features of the problem context through interventions (controllability is high) without causing substantial irreversible damage (risk is low).

- The management-problem context allows for iterative decisionmaking.

- Decisionmakers have clear management objectives and the methodological capacity to use experimentation, option testing, monitoring, assessment, and learning to reduce uncertainty and adjust management decisions in policyrelevant time frames.

- Decisionmakers have both sufficient funding and staffing resources and the political and stakeholder support needed to implement the adaptive management decision methodology as designed and to adjust management decisions based on learning.

- Implementing the adaptive management method will not offend inviolable norms associated with the managementproblem context.

If a particular mangement-problem context does not meet these conditions, neither we nor most adaptive management theorists would

98. See George F. Wilhere, Adaptive Management in Habitat Conservation Plans, 16 CONSERVATION BIOLOGY 20, 20 (2002) (contending that "few HCPs incorporate genuine adaptive management"). Going further, Doremus et al. condemn the use of adaptive management in the ESA permit program as "a justification for going ahead with actions that would not otherwise be allowed." DOREMUS ET AL., supra note 22, at 6. Properly designed, however, that is what adaptive management should provide-i.e., that if uncertainty is high, controllability is high, and risk is low for matters within the scope of the permit, a permit integrating adaptive management to address the uncertainty should be more likely to be approved than one that does not. 
advocate the use of adaptive management unless alternative decisionmaking methods seem even less likely to succeed. Thus, from the outset, we recognize and accept that adaptive management is not appropriate for all, or even most, administrative agency decisionmaking. Nevertheless, there is a subset of contexts where true adaptive management would offer clear advantages over conventional front-end decisionmaking. And there, it is worth examining how current administrative law presents obstacles to adaptive management and how to design new administrative law principles to facilitate use of adaptive management in those applications. We turn now to this task.

\section{ADMINISTRATIVE LAW: VALUES AND OBSTACLES TO ADAPTIVE MANAGEMENT}

Administrative law seeks to protect a range of values, such as due process and public participation, through procedural requirements. The resulting body of law, however, poses significant barriers to agency use of adaptive management. As a result, if administrative law is to accommodate adaptive management, legislators must recognize these barriers and adjust administrative law accordingly. ${ }^{99}$

Even within administrative law, however, some contexts need an adaptive management track far more than others. For example, if an agency orders third parties to engage in adaptive management as part of a permit or license, or if adaptive management is prescribed as part of a court settlement, then the agency should not need a general

99. See, e.g., Alejandro E. Camacho, Transforming the Means and Ends of Natural Resources Management, 89 N.C. L. REV. 1405, 1413-17 (2011) (describing how front-end decisionmaking has proven a barrier to adaptive management); Ahjond S. Garmestani et al., Panarchy, Adaptive Management, and Governance: Policy Options for Building Resilience, 87 NEB. L. REV. 1036, 1045 (2009) ("The fundamental constraint to adaptive management is the current state of administrative law."); Alfred R. Light, Tales of the Tamiami Trail: Implementing Adaptive Management in Everglades Restoration, 22 J. LAND UsE \& ENVTL. L. 59, 96 (2006) ("The basic problem is that the conventional administrative law system is geared to 'command and control,' where activity is regulated using permits that target emissions or discharges for limitation. During the permit period, changes in the terms are not anticipated-i.e., no adaptation based on learning by doing is allowed."); Karkkainen, supra note 45, at 73-76 (recognizing the problems of current administrative law and proposing an adaptive management track); John H. Davidson \& Thomas Earl Geu, The Missouri River and Adaptive Management: Protecting Ecological Function and Legal Process, 80 NEB. L. REV. 816, 859 (2001) (noting that neither administrative rulemaking nor administrative adjudication procedures are designed for adaptive management projects). Notably, this problem is not limited to administrative law in the United States. For example, Canadian scholar Martin Olszynski has argued that Canadian law must provide more clearly for adaptive management ("AM"), "failing which traditional principles of administrative law may thwart attempts to implement AM." Martin Z.P. Olszynski, Adaptive Management in Canadian Environmental Assessment Law: Exploring Uses and Limitations, 21 J. ENVTL. L. \& PRAC. 1, 28 (2010). 
set of administrative procedures to engage in or supervise the specified adaptive management. Instead, the permit, license, or settlement will (or at least should) dictate implementation and oversight procedures, specify monitoring criteria and requirements, provide reopener clauses, or specify penalties for noncompliance. As such, a special adaptive management track is most useful when an agency is seeking to use adaptive management for its own projects or information gathering, or for projects or information gathering done in collaboration with nonregulated entities.

This Part reviews the key features of current administrative law that pose obstacles to agencies' abilities to fully implement adaptive management even in otherwise appropriate applications. These features include requirements for public participation in agencies' decisionmaking, the provision of judicial oversight over most agency decisions and processes, and requirements that drive agencies toward finality. The next Part will then examine how we can preserve these values-albeit in modified form-in an administrative law scheme that allows for real adaptive management.

\section{A. Public Participation}

One of the critical values enshrined in contemporary administrative law is public participation. For example, the APA requires federal agencies (1) in informal rulemaking to give both the general public "notice of proposed rulemaking[s]" and any "interested persons an opportunity to participate in the rulemaking"; 100 (2) in adjudications to "give all interested parties opportunity for" various forms of participation; ${ }^{101}$ (3) in the context of any agency proceeding to give "prompt notice" to interested persons "of the denial in whole or part of a written application, petition, or other request"; 102 and (4) in receiving a petition for agency action, which can be made by any interested person, to respond to that petition. ${ }^{103}$

A host of scholars applaud public participation in administrative processes, and public participation is a core principle of American administrative law theory. As administrative law literature articulates,

100. 5 U.S.C. $§ 553(b),(c)$.

101. Id. $\S 554(\mathrm{c})$.

102. Id. $\S 555(\mathrm{e})$.

103. Id. §§ 553(e), 555(b); see also Nat'l Parks Conservation Ass'n v. U.S. Dep't of the Interior, 794 F. Supp. 2d 39, 44 (D.D.C. 2011) (holding that "an agency "is required to at least definitively respond to ... [a] petition-that is, to either deny or grant the petition" " (quoting Families for Freedom v. Napolitano, 628 F. Supp. 2d 535, 540 (S.D.N.Y. 2009))). 
public participation in agency decisionmaking is valuable for its own sake, ${ }^{104}$ but it also promotes administrative legitimacy and public acceptance, ${ }^{105}$ encourages the agency's consideration of diverse and divergent points of view, ${ }^{106}$ promotes transparency in agency decisionmaking, ${ }^{107}$ checks unbridled agency discretion, 108 and increases

104. See Lumen N. Mulligan \& Glen Staszewski, The Supreme Court's Regulation of Civil Procedure: Lessons from Administrative Law, 59 UCLA L. REV. 1188, 1244 (2012) (noting the importance of public participation in agency decisionmaking so decisionmakers consider a range of different perspectives); Lisa Blomgren Bingham, The Next Generation of Administrative Law: Building the Legal Infrastructure for Collaborative Governance, 2010 WIS. L. REV. 297, 316-17 (discussing the use of the phrase "public participation" in administrative law and the specific processes for implementing public participation); William Funk, Public Participation and Transparency in Administrative Law-Three Examples as an Object Lesson, 61 ADMIN. L. REV. 171, 171-72 (2009) (stating that public participation and transparency "are hallmarks of American administrative law" and examining several statutory schemes designed to increase public participation); Richard B. Stewart, Essay, Administrative Law in the Twenty-First Century, 78 N.Y.U. L. REV. 437, 444 (2003) ("Public participation through rulemaking and other processes ... [has] become [a] central foundation] of administrative law practice.").

105. Mulligan \& Staszewski, supra note 104, at 1244; Kathryn A. Watts, Constraining Certiorari Using Administrative Law Principles, 160 U. PA. L. REV. 1, 23 (2011); Nina A. Mendelson, Rulemaking, Democracy, and Torrents of E-Mail, 79 GEO. WASH. L. REv. 1343, 1343 (2011); Jessica Mantel, Procedural Safeguards for Agency Guidance: A Source of Legitimacy for the Administrative State, 61 ADMIN. L. REV. 343, 388 (2009); Jacob E. Gersen \& Anne Joseph O'Connell, Deadlines in Administrative Law, 156 U. PA. L. REV. 923, 972 (2008); Stephen M. Johnson, Good Guidance, Good Grief!, 72 Mo. L. REV. 695, 702-03 (2007); Stephen M. Johnson, The Internet Changes Everything: Revolutionizing Public Participation and Access to Government Information Through the Internet, 50 ADMIN. L. REV. 277, 289 (1998) ("Public participation is essential to sound agency decisionmaking because ... it instills a sense of legitimacy in the public for the agency's decisions."); Robert L. Glicksman \& Stephen B. Chapman, Regulatory Reform and (Breach of) the Contract with America: Improving Environmental Policy or Destroying Environmental Protection?, KAN. J.L. \& PUB. POL'Y 9, 12 \& n.50 (1996); Keith Werhan, Delegalizing Administrative Law, 1996 U. ILL. L. REV. 423, 445; Ronald M. Levin, Nonlegislative Rules and the Administrative Open Mind, 41 Duke L.J. 1497, 1505 (1992); Dennis Thompson, Bureaucracy and Democracy, in Democratic Theory AND Practice 235, 237-50 (Graeme Duncan ed., 1983); Michael Asimow, Public Participation in the Adoption of Interpretive Rules and Policy Statements, 75 Mich. L. REv. 520, 529, 574 (1977); Ernest Gellhorn, Public Participation in Administrative Proceedings, 81 YALE L.J. 359, 381 (1972).

106. Mulligan \& Staszewski, supra note 104, at 1244; Funk, supra note 104, at 179-80; Stewart, supra note 104, at 1713-15; Jim Rossi, Participation Run Amok: The Costs of Mass Participation for Deliberative Agency Decisionmaking, 92 Nw. U. L. REV. 173, 187 (1997); KENNETH Culp Davis \& Richard J. Pierce, JR., Administrative LaW Treatise 424 (3d ed. 1994); Peter D. Holmes, Paradise Postponed: Suspensions of Agency Rules, 65 N.C. L. REV. 645, 688 (1987); Barry Boyer \& Errol Meidinger, Privatizing Regulatory Enforcement: A Preliminary Assessment of Citizen Suits Under Federal Environmental Laws, 34 BuFF. L. REv. 833, 843-44 (1985).

107. Sarah Tran, Administrative Law, Patents, and Distorted Rules, 80 GEo. WASH. L. Rev. 831, 877 (2012) ("By forcing agencies to incorporate public participation into their decisionmaking processes, the APA renders agency decisions more transparent and better informed.”); Bingham, supra note 104, at 334-41; Funk, supra note 104, at 171-72.

108. Watts, supra note 105, at 36; Stewart, supra note 104, at 1715-18; Ann Bray, Comment, Scientific Decision Making: A Barrier to Citizen Participation in Environmental Agency Decision 
the amount of information available to decisionmakers, including information regarding the regulated entities' and general public's preferences. ${ }^{109}$

Adaptive management threatens, or at least is perceived to threaten, the promotion of public participation in traditional administrative law. One possible response to this objection is that administrative law theory has increasingly criticized extensive public participation requirements because they create burdensome inefficiency in agency decisionmaking, ${ }^{110}$ a criticism resonant with the impediments that administrative law creates for true adaptive management. We do not, however, rest our promotion of adaptive management on the devaluation of public participation in agency decisionmaking; we admit, moreover, that there is a fundamental tension between continual public deliberative debate over an agency's action and that agency's commitment to principled adaptive management over time. But the inescapable trade-off is that "the blackletter law ... constrains how far agencies can go with a/m-lite, as truly iterative 'learning while doing' may at some point run afoul of . . . the demands of public notice and comment." 111 In natural resources law, for example, "environmental protection interests are concerned that [adaptive management] will lead to closed-door resource development approvals."112 Moreover, public participation in some prominent environmental adoptions of adaptive management, such as for Habitat

Making, 17 WM. Mitchell L. REV. 1111, 1113 (1991); BERNARD SChWARTZ, AdMINISTRATIVE LAW 266-68 (1978).

109. Tran, supra note 107 , at 877 ; Mendelson, supra note 105 , at $1344-46$; Watts, supra note 105, at 62; Mantel, supra note 105, at 388; Gersen \& O'Connell, supra note 105, at 972; Rossi, supra note 106, at 186-87; Holmes, supra note 106, at 688.

110. Mantel, supra note 105, at 388-89. See generally David L. Markell \& Tom R. Tyler, Using Empirical Research to Design Government Citizen Participation Processes: A Case Study of Citizens' Roles in Environmental Compliance and Enforcement, 57 U. KAN. L. REV. 1 (2008) (empirically assessing the role of public participation in administrative law); Rossi, supra note 106 (exploring the idea that public participation can overwhelm agency processes); Edward Rubin, The Myth of Accountability and the Anti-Administrative Impulse, 103 Mich. L. REv. 2073 (2005) (exploring the limits of traditional models of administrative process, including public participation); Mark Seidenfeld, The Psychology of Accountability and Political Review of Agency Rules, 51 DuKE L.J. 1059 (2001) (same); Mark Seidenfeld, supra note 12, at 483-84 (same); Mark Seidenfeld, Empowering Stakeholders: Limits on Collaboration as the Basis for Flexible Regulation, 41 WM. \& MARY L. REV. 411 (2000) (same); Stewart, supra note 104 (same); Mark Seidenfeld, supra note 12, at 483-84 (same); Mark Seidenfeld, A Civic Republican Justification for the Bureaucratic State, 105 HARV. L. REV. 1511, 1541 (1992) ("[T] he problem today is not a lack of responsiveness to popular interests, but rather an overresponsiveness to immediate and fickle political whims and to powerful factions ....”).

111. Ruhl \& Fischman, supra note 6, at 480.

112. Id. at 478. 
Conservation Plans under the ESA, has been limited and subject to demands for greater public input. ${ }^{113}$

This tension, nevertheless, can be resolved by aligning public participation requirements and opportunities with the structured decisionmaking process that adaptive management demands, achieving a balance between public participation and agency effectiveness. As Jessica Mantel has pointed out in a different context,

\begin{abstract}
A vigorous administrative state that efficiently and effectively serves the public interest is jeopardized by excessive procedural requirements that consume significant agency resources and unnecessarily delay agency action. Accordingly, preserving the ability of government officials to meet society's needs depends on reaching a delicate balance between administrative processes that advance the legitimacy of the regulatory state while preserving its effectiveness. The challenge, then, is to construct administrative processes . . . that strike this balance. ${ }^{114}$
\end{abstract}

As we discussed in Part II, adaptive management theorists already encourage stakeholder participation in the setup phase of adaptive management, and this setup phase lends itself well to traditional modes of public participation in agency decisionmaking, especially informal rulemaking. Moreover, while direct public participation must be constrained in the iterative implementation phase of adaptive management if true adaptive agency decisionmaking is to be allowed, the law can easily accommodate transparency concerns by requiring agencies to regularly produce public reports on their implementation "dial twiddling" and to publicly publish monitoring results at regular intervals. Finally, the iterative structure of adaptive management-if coupled with a "reset button" requirement that agencies periodically return to the setup phase (as we propose below) ${ }^{115}$ _provides parallel iterative opportunities for public participation. Moreover, this public participation would be enhanced in subsequent decisionmaking rounds by the availability of agency reports and the accumulation of monitoring data. In other words, adaptive management readily lends itself to direct public participation in the agency's periodic "big decisions" - the defining and redefining of specific management goals and the periodic evaluation and reevaluation of management measures employed-even as it requires administrative law to carve out space for a certain amount of discretionary implementation in between. The design issue posed, of course, is how

113. Id. at $479-80$.

114. Mantel, supra note 105, at 389. See also Peter A. Pfohl, Congressional Review of Agency Rulemaking: The 104th Congress and the Salvage Timber Directive, 14 J.L. \& PoL. 1, 25-26 (1998) (discussing how Congress achieved this same kind of balance in the distinction between noticeand-comment rulemaking and rulemaking exempt from these procedural requirements).

115. See infra Part IV.B.3. 
far to spread apart those "big decisions" (or "reset buttons"), which we deal with below. ${ }^{116}$

\section{B. Judicial Review}

The availability of judicial review is one of the hallmarks of contemporary administrative law in the United States. ${ }^{117}$ Indeed, historically, judicial review was one of the procedural safeguards that allowed the U.S. Supreme Court to bless the administrative state as constitutional, despite the lack of mention of administrative agencies in the U.S. Constitution and despite their engagement in adjudications. ${ }^{118}$ Judicial review advances several important values in administrative law. Most obviously, it ensures that agencies comply with congressional dictates and hence oversees exercises of agency discretion. ${ }^{119}$ Scholars also laud judicial review for its ability to prevent agencies from being "captured" by regulated entities contrary to the broader public interest ${ }^{120}$ and to promote reasoned and reasonable

116. See generally infra Part IV.B.

117. Stewart, supra note 104, at 444; Emily Hammond \& David L. Markell, Administrative Proxies for Judicial Review: Building Legitimacy from the Inside-Out, 37 HARV. ENVTL. L. ReV. 313, 314, 320-21 (2013).

118. E.g., Atlas Roofing Co. v. Occupational Safety \& Health Review Comm'n, 430 U.S. 442, 450 (1977) (holding that Congress could create a new cause of action in the government for civil penalties under the Occupational Safety and Health Act enforceable in an administrative agency where there is no jury trial).

119. Carrie Leonetti, Watching the Hen House: Judicial Rulemaking and Judicial Review, 91 NEB. L. REV. 72, 117 (2012); Wendy Wagner, Revisiting the Impact of Judicial Review on Agency Rulemakings: An Empirical Investigation, 53 WM. \& MARY L. REV. 1717, 1724 (2012); Jack M. Beermann, Common Law and Statute Law in Administrative Law, 69 ADMIN. L. REV. 1, 12 (2011); Watts, supra note 105, at 38; Eric Biber, The Importance of Resource Allocation in Administrative Law, 60 Admin. L. Rev. 1, 24 (2008); Robert L. Glicksman, Securing Judicial Review of Agency Inaction (and Action) in the Wake of Norton v. Southern Utah Wilderness Alliance, in STRATEGIES For ENVIRONMENTAL SuCCESS In AN UNCERTAin Judicial Climate 163, 169 (Michael Allen Wolf ed., 2005); Lisa Schultz Bressman, Judicial Review of Agency Inaction: An Arbitrariness Approach, 79 N.Y.U. L. REV. 1657, 1687-89 (2004); Stewart, supra note 104, at 1669-70, 1673-76; STEPHEN G. Breyer et Al., Administrative LaW and Regulatory Policy: Problems, Text, and Cases 985 (5th ed. 2002); Steven P. Croley, State Administrative Law Reform: Recent Experience in Michigan, 8 Widener J. PuB. L. 347, 396-97 (1999); Thomas O. Sargentich, The Critique of Active Judicial Review of Administrative Agencies: A Reevaluation, 49 ADMIN. L. REV. 599, 634 (1997); Cass R. Sunstein, Reviewing Agency Inaction After Heckler v. Chaney, 52 U. CHI. L. REv. 653, 668 (1985); Philip J. Harter, The Political Legitimacy and Judicial Review of Consensual Rules, 32 AM. U. L. Rev. 471, 485-86 (1983); Richard J. Pierce \& Sidney A. Shapiro, Political and Judicial Review of Agency Action, 59 TEX. L. REV. 1175, 1178 (1981).

120. Wagner, supra note 119, at 1717-24; Cass R. Sunstein, Interest Groups in American Public Law, 38 StAN. L. ReV. 29, 63 (1985). 
agency decisionmaking. ${ }^{121}$ Finally, judicial review provides another route for promoting transparent agency decisionmaking and public participation in agency processes. ${ }^{122}$

Nevertheless, judicial review as currently constituted imposes two primary barriers to effective adaptive management. First, regardless of the standard used, the very availability of judicial review for each final agency decision is too intrusive, threatening agencies' authority and practical ability to adjust adaptive management projects and management measures as they learn without being immediately hauled into court for every little dial adjustment. Admittedly, review pursuant to the APA and most other statutes is limited to "final agency action," 123 suggesting that some minor agency "dial twiddling" might be exempt from judicial review even under current law, especially if courts were to classify adaptive management decisions as being "committed to agency discretion." However, as the U.S. Supreme Court recently confirmed, actions that a federal agency considers tentative, preliminary, or experimental may nonetheless be considered "final," especially if the decision concludes an agency determination of some sort or creates legal consequences. ${ }^{124}$ Moreover, the very fact that there is litigation challenging iterative-phase decisions still disrupts the structured adaptive management decisionmaking process-even if the agency eventually prevails.

Second, current standards for judicial review do not match the process of adaptive management. For example, agencies must demonstrate that their decisions are reasonable (not arbitrary and capricious) attempts to fulfill statutory mandates and goals. However, a recent comprehensive study of how courts have treated agency attempts to employ adaptive management in natural resources law concluded that "adaptive management procedures, no matter how finely crafted, cannot substitute for showing that a plan will meet the substantive management criteria required by law." 125 On the other

121. Hammond \& Markell, supra note 117, at 121; Wagner, supra note 119, at 1723-24.; Ronald J. Krotoszynski, Jr., "History Belongs to the Winners": The Bazelon-Levanthal Debate and the Continuing Relevance of the Process / Substance Dichotomy in Judicial Review of Agency Action, 58 Admin. L. REV. 995, 1009 (2006); Croley, supra note 119, at 396-97; Susannah T. French, Judicial Review of the Administrative Record in NEPA Litigation, 81 CALIF. L. REV. 929, 944 (1993); LOUIS L. JAFFE, JUdicial CONTROL OF ADMINistrative ACTION 601 (1965).

122. Matthew Groves, Should We Follow the Gospel of the Administrative Decisions (Judicial Review) Act 1977 (CTH)?, 34 MELB. U. L. REV. 736, 760 (2010).

123. E.g., 5 U.S.C. $\S 704$ (2012).

124. Sackett v. EPA, 132 S. Ct. 1367, 1371-72, 1374 (2012) (citations omitted).

125. Ruhl \& Fischman, supra note 6 , at 445. 
hand, the study also revealed a judicial receptiveness to adaptive management in theory, concluding that

regardless of the particular outcome of judicial review, courts generally wish to support the trend toward adaptive management .... Courts sometimes explicitly state that they do not wish to create disincentives for using adaptive management . . . . It is fair to conclude from this litigation that courts, despite their roots in the conventional administrative law model of a phase change at the time of final agency action, generally give agencies wide berth within statutory constraints to alter traditional planning approaches to accommodate adaptive management. ${ }^{126}$

Thus, when administrative law itself can accommodate adaptive management, the courts will also try to support its use.

Nevertheless, the fact that courts generally support adaptive management in natural resources law does not prevent them from overturning agency attempts to employ adaptive management, particularly when the courts are not convinced that the agency's adaptive management plan will achieve substantive statutory requirements. ${ }^{127}$ Moreover, under current principles of administrative law, it is difficult for courts to "directly distinguish legitimate adaptive management from imposters." 128 One reason is that no legislation requires an agency to adhere to legitimate adaptive management methodology, leaving courts with inappropriate procedural requirements against which to judge an agency's invocation of adaptive management. ${ }^{129}$ For example, as much as adaptive management theory advocates that agencies "design[] management actions as experiments so that they promote learning to reduce uncertainty," the reality is that "this crucial element of adaptive management is not generally required by law and courts will not impose it."130

\section{Finality}

One of the entrenched values of contemporary administrative law is finality - the insistence on final resolutions by administrative agencies that will be definitively upheld or rejected by the courts. Thus, for example, while "agency action" subject to the APA includes a broad

126. $I d$. at $446-47$.

127. $I d$. at $461-70$.

128. Id. at 470 .

129. As Ruhl and Fischman observe, "a court upholding an a/m-lite approach does not necessarily endorse the practice as advancing the goals of either law or conservation policy. It simply means that the use of $\mathrm{a} / \mathrm{m}$-lite did not run afoul of any specific legal requirement or substitute for a required finding or procedure." Id. at 446. Moreover, "courts may approve agency actions that involve terrible applications of adaptive management." Id.

130. Id. at 471. 
range of agency activities - "the whole or a part of an agency rule, order, license, sanction, relief, or the equivalent or denial thereof, or failure to act"131_ reviewable agency actions are limited to those "made reviewable by statute and final agency action for which there is no other adequate remedy in a court." 132 More generally, nonfinal agency action is of no legal effect, a fact that the U.S. Supreme Court recently underscored in its evaluation of administrative compliance orders. ${ }^{133}$

Investments in up-front decisionmaking, and hence an agency's drive toward finality, are only increased when its actions are subject to additional requirements for regulatory impact analyses beyond the basic explanations that the APA's (or state equivalent's) "arbitrary and capricious" standard would require. Regulatory impact analyses can be legion, especially for federal agencies, but two of the most intensive are environmental-impact analyse ${ }^{134}$ and cost-benefit/risk-benefit/riskrisk analyses. ${ }^{135}$

Of course, valuing finality in administrative law reflects the American legal system's more pervasive valuation of finality undergirding a variety of legal doctrines. As Dan Tarlock has summarized,

We follow Hume and Bentham and seek to confirm settled expectations unless there is a compelling overriding reason, usually one grounded in constitutionally protected norms such as free expression or racial equality. Once a decision is rendered, we expect parties to forever abide by the outcome. Finality takes many forms. Sometimes, it is represented by express doctrines and legislation, such as res judicata, statutes of limitation, and the doctrine of vested rights. On other occasions, finality is implicit. For example, the premise behind an environmental impact statement is that once environmental damage has been

131. 5 U.S.C. $§ 551(13)$ (2012).

132. Id. $§ 704$ (emphasis added).

133. See Sackett v. EPA, 132 S. Ct. 1367, 1371-74 (2012) (holding that EPA administrative compliance orders issued pursuant to the Clean Water Act are final agency actions subject to judicial review largely because those orders do have immediate legal effects).

134. E.g., National Environmental Policy Act ("NEPA"), 42 U.S.C. $§ 4332$ (requiring federal agencies to produce environmental-impact statements "in every recommendation or report on proposals for legislation and other major Federal actions significantly affecting the quality of the human environment"); California Environmental Quality Act ("CEQA"), CAL. PUB. RES. CODE $\S \S 21000,21002$ (2012) (explaining California's environmental-impact report requirements); New York State Environmental Quality Review Act ("SEQRA"), N.Y. ENVTL. CONSERV. LAW § 8 (2012) (explaining New York's environmental-impact statement requirements). For a discussion of how these statutes can each inhibit adaptive management and promote adaptive management, see Ruhl \& Fischman, supra note 6, at 472-75.

135. E.g., Improving Regulation and Regulatory Review, Exec. Order No. 13,563, 76 Fed. Reg. 3821 (Jan. 18, 2011) (reaffirming the requirement of cost-benefit analyses for regulatory actions); Regulatory Planning and Review, Exec. Order No. 12,866, 58 Fed. Reg. 51,735 (Sept. 30, 1993) (requiring that agencies perform a cost-benefit analysis in determining whether and how to regulate). 
fully disclosed, a one-time decision can be made on the merits of the activity, and even if the activity will irrevocably alter the environment, the decision is legitimate and final. ${ }^{136}$

The point here is not that finality is bad per se, but rather that the many procedural drivers toward finality in administrative law- the extensive requirements for front-end justification to produce a judicially defensible final agency action-effectively end further deliberation and debate over the agency's decision, both publicly and within the agency. ${ }^{137}$ As such, they act as barriers to full agency implementation of true adaptive management.

Indeed, because administrative law drives agencies toward finality, that body of law has little place for continual agency experimentation and adaptation, as adaptive management requires. ${ }^{138}$ Instead, it both assumes and reifies a world where agency decisions are, most essentially, onetime and isolated events, not a continually evolving series of refinements-or, as adaptive management scholars have put it, "toggle" choices rather than "dial" adjustments. ${ }^{139}$

This characterization is perhaps most obvious for agency adjudications-permitting, licensing, certification, and other decisions that apply laws to the actions of one or a discrete collection of individuals or entities. Rules, in contrast, are by definition amenable to amendment and replacement over time, ${ }^{140}$ allowing for some agency learning and adjustment. Nevertheless, under contemporary administrative law, each rulemaking effort-even the amendment or

136. A. Dan Tarlock, The Nonequilibrium Paradigm in Ecology and the Partial Unraveling of Environmental Law, 27 LoY. L.A. L. REv. 1121, 1140 (1994) (emphasis added).

137. As Ruhl and Fischman have explained:

[F]inal agency action [is the step] when the government throws the switch and makes the decision it will implement and defend if challenged in court. The legal system regards the point of final agency action as a phase change when the fluid period of deliberation ends and implementation/defense of a fixed record and plan of action begins.

Ruhl \& Fischman, supra note 6, at 436-37 (citing Citizens to Pres. Overton Park v. Volpe, 401 U.S. 402, 419-20 (1971)).

138. As Susskind and Secunda have noted:

Adaptive management theory treats almost all governmental interactions as experiments, from which we can continuously learn what works and what does not. Adaptive management envisions a continuous process of institutional transformation, as entities "evolve" their philosophies and strategies through continuous assessment and improvement. Change is driven by a constant flow of information gathered via purposeful experimentation.

Susskind \& Secunda, supra note 18, at 157.

139. See Ruhl \& Fischman, supra note 6, at 438 ("The legal view of a resource management plan is that it comprehensively evaluates all rational considerations at once and then flips a toggle switch; the adaptive management approach twiddles the dial as information trickles in.").

140. See 5 U.S.C. $§ 551(5)$ (2012) (defining "rule making" to include not only the initial promulgation of a rule but also the processes of amending and repealing rules). 
modification of a prior rule-is evaluated as a separate legal event, not an ongoing process of agency learning and adaptation. Indeed, the courts have debated the degree of deference to which a federal agency is entitled when it amends a regulation, ${ }^{141}$ one indication that amendments are separate legal events rather than part of an ongoing agency decisionmaking process. In essence, the agency is supposed to "get it right" at each pronouncement and to "keep it right" until new information or changed circumstances justifies a change. There is very little room, even under the arbitrary and capricious standard, for an agency to say honestly, "We have only a vague idea now of how to achieve what we want to achieve, but we think this decision is a good start for now." 142

In contrast, adaptive management allows-even demandscontinual managerial flexibility in the face of system complexity. ${ }^{143} \mathrm{In}$ the realm of ecology and natural resources management, for example, adaptive management "was originally the domain of scientists frustrated with policy makers' failure to grasp the complexity of the natural world." 144 Ecosystems, of course, are one of the paradigmatic complex systems - in the words of C.S. Holling, "complex, nonlinear systems where discontinuous behavior and structural change are the norm." 145

Nevertheless, while ecologists rejected an equilibrium paradigm for ecosystems decades ago, environmental law has not caught up. ${ }^{146}$ As Dan Tarlock, among other scholars, has recognized, "The major institutional change necessitated by the nonequilibrium paradigm is the need to apply adaptive management to biodiversity protection." 147 However, as he also has recognized, "The idea that all management is

141. E.g., Rust v. Sullivan, 500 U.S. 173, 186-87 (1991) (explaining that an agency "must be given ample latitude 'to adapt [its] rules and policies to the demands of changing circumstances." (quoting Motor Vehicle Mfrs. Ass'n v. State Farm Mut. Auto. Ins. Co., 463 U.S. 29, 42 (1983))).

142. See Tarlock, supra note 136, at 1141-44 (describing the difficulties agencies encountered when trying to implement adaptive management).

143. Ruhl \& Fischman, supra note 6 , at 424.

144. Wiersema, supra note 47 , at 1245 .

145. C.S. Holling, What Barriers? What Bridges?, in BARRIERS AND BRIDGES TO THE RENEWAL of Ecosystems AND Institutions 3, 19 (Lance H. Gunderson et al. eds., 1995); see also Ruhl \& Fischman, supra note 6, at 428-31 (describing the evolution of views in natural resources policy).

146. See Tarlock, supra note 136, at 1122-23, 1125-30 (discussing the flaws of the equilibrium approach and the failure of policy makers to notice the scientific shift away from it); see also Ruhl \& Fischman, supra note 6, at 424-27 (arguing that, while adaptive management "has become infused into the natural resources policy world to the point of ubiquity, surfacing in everything from mundane agency permits to grand presidential proclamations," agencies are actually practicing "a/m lite" and courts do not support robust adaptive management).

147. Tarlock, supra note 136, at 1139. 
an ongoing experiment poses a profound challenge to our legal system because it undermines a core principle of procedural and substantive fairness: finality." 148 The demand in administrative law for immediate finality again thus acts as a barrier to agency implementation of true adaptive management.

\section{A New Approach to Administrative Law}

Annacoos Wiersema has summarized the new governance literature from a variety of disciplines:

[W] live in a complex society where laws designed for particular purposes can have unanticipated consequences, where bureaucracy is too slow and cumbersome to respond quickly and efficiently enough to those consequences, and where the traditional structure of top-down lawmaking is under siege as too rigid, too hierarchical, and too contentious to achieve its goals. The world we live in, as legal writers spanning a range of fields tell us, requires new forms of governance. ${ }^{149}$

Administrative law in particular has already evolved several times to accommodate changing values and to fix perceived problems.

Nevertheless, administrative law has not yet evolved to embrace instances when agencies truly need additional kinds of flexibility. Notably, however, when Congress and the courts fully appreciate the need for ongoing federal agency flexibility and nimbleness in the face of changing circumstances, they exempt the agency from APA requirements. One prominent example is the Federal Reserve Board's ${ }^{150}$ open market decisions, which include its determinations of interest rates and discount rates. Specifically, the Federal Reserve System's Federal Open Market Committee ("FOMC") "sets the federal funds rate at a level it believes will foster financial and monetary conditions consistent with achieving its monetary policy objectives, and it adjusts that target in line with evolving economic developments." 151 Thus, although its decisionmaking process is rarely labeled as such, the FOMC engages in a form of continual adaptive management with the goal of maintaining economic stability in the face of complex and

148. $I d$. at 1140 .

149. Wiersema, supra note 47 , at 1241 (footnotes omitted).

150. Congress created the Federal Reserve System in 1913 through the Federal Reserve Act. Federal Reserve Act, ch. 6, 38 Stat. 251 (1913) (codified as amended in scattered sections of 12 U.S.C.). The "Federal Reserve Board," for purposes of this discussion, is more properly named the Federal Open Market Committee, which "oversees open market operations" and "influence[s] overall monetary and credit conditions." BD. OF GOVERnORS OF THE FED. RESERVE SYS., ThE Federal Reserve System: Purposes And FunCtions 3 (9th ed. 2005), available at http://www.federalreserve.gov/pf/pdf/pf_complete.pdf.

151. BD. OF GOVERNORS OF THE FED. RESERVE Sys., supra note 150, at 16. 
changing economic realities. Moreover, the U.S. Supreme Court classified the FOMC's open market (domestic policy) decisions as interagency memoranda that are generally exempt from APA procedural requirements, ${ }^{152}$ while Congress provided special procedures for those decisions. ${ }^{153}$ Finally, the federal courts have refused judicial oversight of these FOMC decisions. ${ }^{154}$ As Judge Augustus Hand, writing for himself, Judge Learned Hand, and Judge Swan, once explained:

\begin{abstract}
It would be an unthinkable burden on any banking system if its open market sales and discount rates were to be subject to judicial review. Indeed, the correction of discount rates by judicial decree seems almost grotesque, when we remember that conditions in the money market often change from hour to hour, and the disease would ordinarily be long over before a judicial diagnosis could be made. ${ }^{155}$
\end{abstract}

Thus, U.S. administrative law is no stranger to differentiated procedural requirements-including dramatically increased agency discretion-that reflect the reality that regulatory contexts vary. More specifically, Congress, through the administrative laws it has passed, already acknowledges that some such contexts require rapid adjustments to changing circumstances in order to achieve higher-level legislative and regulatory goals. Adaptive management could be one of the most valuable of the new governance tools to deal with the complexity and uncertainty of the contemporary world-a world that is subject to, among other things, continual and emerging stresses from phenomena such as climate change and rippling global economic crashes. ${ }^{156}$ Nevertheless, as Brad Karkkainen suggested as early as

152. Fed. Open Mkt. Comm. v. Merrill, 443 U.S. 340, 352-53 (1979).

153. 12 U.S.C. $\S \S 247 a, 263(b)-(c)$ (2012). The U.S. Supreme Court summarized the FOMC's procedures as follows:

The FOMC meets approximately once a month to review the overall state of the economy and consider the appropriate course of monetary and open market policy. The Committee's principal conclusions are embodied in a statement called the Domestic Policy Directive. The Directive summarizes the economic and monetary background of the FOMC's deliberations and indicates in general terms whether the Committee wishes to follow an expansionary, deflationary, or unchanged monetary policy in the period ahead. The Committee also attempts to agree on specific tolerance ranges for the growth in the money supply and for the federal funds rate.

Merrill, 443 U.S. at $344-45$.

154. E.g., Comm. for Monetary Reform v. Bd. of Governors of Fed. Reserve Sys., 766 F.2d 538, 543-44 (D.C. Cir. 1985) (affirming the dismissal of a lawsuit challenging the FOMC's decisions on standing and separation of powers grounds).

155. Raichle v. Fed. Reserve Bank of N.Y., 34 F.2d 910, 915 (2d Cir. 1929).

156. In the natural-resources-management context, for example, Professor Barbara Cosens has published pioneering work on the need for adaptive management as a tool for increasing resilience and coping with both system complexity and climate change. See, e.g., Barbara Cosens, Resilience and Law as a Theoretical Backdrop for Natural Resource Management: Flood Management in the Columbia River Basin, 42 ENVTL. L. 241, 252 (2012) (footnote omitted) 
2005, ${ }^{157}$ adaptive management requires a different form of administrative law. The next Part thus proposes a different vision of the law governing agencies and describes the contexts in which adaptive management would be valuable.

\section{ADDING AN ADAPTIVE MANAGEMENT TRACK TO ADMINISTRATIVE LAW}

To the extent that agencies have been attempting to implement adaptive management, they generally do so at the limits of their administrative discretion. ${ }^{158}$ While an agency's desire to push the limits of its discretion to achieve a better regulatory or management program might be understandable, such stretching renders federal agencies vulnerable to "abuse of discretion" litigation, ${ }^{159}$ and in some states it is flatly illegal.160 Indeed, concerns over agency discretion-and

("Resilience scholars call on adaptive management to allow adjustment to the high degree of uncertainty associated with the complex interactions and feedbacks in a social-ecological system, an approach that would be necessary as nonstructural measures are implemented and their true impact measured."); Barbara Cosens, Transboundary River Governance in the Face of Uncertainty: Resilience Theory and the Columbia River Treaty, 30 J. LAND RESOURCES \& ENVTL. L. 229, 263 (2010):

[W] hile existing frameworks for agency management are appropriate for management and adaptive management in the face of predictable variability, the existing framework may not be appropriate for response in a complex system in which uncertainty is "not reducible by further research," or . . . to "wicked" problems in which the actors are unable to agree on either the problem definition or the solution.

See also Camacho, supra note 99, at 1415-16 (noting that "scholars and agencies increasingly endorse the incorporation of adaptive management to cope with the uncertainty likely to arise with climate change"); Camacho, supra note 37, at 10-13 (advocating more generally for adaptive governance).

157. Professor Karkkainen wrote:

One might even envision administrative law proceeding on two tracks: ordinarily the familiar "fixed rule" track will apply, except in circumstances where the agency can justify, according to well-understood standards, shifting to the adaptive management track, and at that point a second set of adaptive management administrative law principles would kick in, requiring different procedures and further justifications for changes in the course of action.

Karkkainen, supra note 45, at 75. Professor Karkkainen did not, however, actually propose such a statute. See also Ruhl, supra note 10, at 54 (suggesting that we are a long way from having a National Adaptive Management Act).

158. See Susskind \& Secunda, supra note 18, at 166 (noting that the "EPA's uneasiness regarding the use of its administrative discretion undermined Project XL from its inception").

159. E.g., ABF Freight Sys., Inc. v. NLRB, 510 U.S. 317, 323-25 (1994) (holding that the National Labor Relations Board's decision to award reinstatement and back pay was not an abuse of discretion despite the employee's false testimony).

160. See, e.g., Dep't of Transp. v. Pan Am. Constr. Co., 338 So. 2d 1291, 1293-94 (Fla. Dist. Ct. App. 1976) (holding that an agency cannot, by rule, expand its statutory authority), appeal dismissed, 345 So. 2 d 427 (Fla. 1977). 
mechanisms to constrain that discretion-have been a substantial focus in administrative law from its creation. ${ }^{161}$ Given adaptive management's value for the administrative toolbox, it would be far better to provide agencies with explicit statutory authority to engage in it 162 _statutory authority that simultaneously addresses the administrative law barriers to adaptive management identified in Part III. This Part begins by examining how an administrative law scheme that promotes adaptive management could simultaneously preserve and promote traditional administrative law values. It then examines what other features are necessary both to ensure that agencies engage in true adaptive management, not $\mathrm{a} / \mathrm{m}$ lite, and to provide procedural safeguards against ineffective or damaging adaptive management experiments. ${ }^{163}$

\section{A. Preserving Traditional Administrative Law Values in the Adaptive Management Process}

Redesigning administrative law to allow for adaptive management does not require abandoning traditional administrative law values-quite the opposite. Indeed, commentators on adaptive management have identified public participation to be a critical component of any adaptive management scheme. In particular, they advocate public participation at critical stages of the project or management measure, ${ }^{164}$ access to judicial review, ${ }^{165}$ and provision for some sort of emergency outside intervention if the project or management measure's implementation of adaptive management goes too far awry or actively undermines the substantive goals of the

161. Stewart, supra note 14, at 1676-82.

162. See Ruhl \& Fischman, supra note 6, at 480-81 ("Only Congress can let agencies break out of the a/m-lite mold without fear of public, industry, and judicial pushback."); Susskind \& Secunda, supra note 18, at 166 (arguing for "passage of legislation specifically defining and authorizing [EPA's Project XL] implementation," which "would minimize the need for agency staff to squeeze XL experiments under the umbrella of tortured regulatory reinterpretation").

163. See, e.g., Lawrence Susskind et al., Collaborative Planning and Adaptive Management in Glen Canyon: A Cautionary Tale, 35 ColuM. J. ENVTL. L. 1, 4 (2010) (arguing that "[a]fter thirteen years and millions of dollars, the [Glen Canyon Adaptive Management Program] has failed to stabilize or otherwise improve the quality of the fragile downstream ecosystem").

164. See Susskind \& Secunda, supra note 18, at 162-63, 164 (arguing that stakeholders should be encouraged to participate in individual projects and proposals, and suggesting the creation of a funding mechanism to help stakeholders lacking sufficient resources to participate).

165. Id. at 166 (arguing that "any affected party [should have statutory right to] petition to have the [EPA] project[s] stopped immediately in federal court"). 
regulatory regime. ${ }^{166}$ Incorporating safeguard mechanisms such as these will support the legitimacy of adaptive management processes, without which adaptive management is doomed;167 the challenge will be not to smother adaptive management in the process.

Finality is, perhaps obviously, the traditional administrative law value most in tension with adaptive management. Even here, however, we can accommodate traditional values, given that commentators expect visible progress toward, if not achievement of, stated goals within a reasonable period of time ${ }^{168}$ _ "reasonable" being judged by the management project's scale. In other words, we should judge finality in this context not by the administrative process itself, but rather by the goals that the adaptive management project is trying to achieve.

The key to preserving these administrative law values while allowing agencies to implement true adaptive management is for administrative law to embrace and absorb adaptive management's periodicity. Specifically, we should recast administrative procedure not as a one-time, final-agency-decision-then-judicial-review process, but rather as a recurring process of punctuated "final" decisionmaking, public participation, and judicial review somewhat akin to continuing jurisdiction in the courts. Reenvisioned in this light, administrative law can actually better hold agencies accountable to their adaptive management responsibilities while simultaneously providing for more public participation and judicial oversight than the current $\mathrm{a} / \mathrm{m}$ lite compromise allows.

\section{Public Participation}

While, as noted above, traditional administrative law provisions governing public participation are generally considered a barrier to agency use of true adaptive management, ${ }^{169}$ it is worth emphasizing

166. See id. at 165-66 (arguing that proposed legislation allowing for adaptive management in environmental compliance through Project XL should provide that "EPA and/or a state environmental authority can unilaterally order the experiment to cease").

167. See Barbara A. Cosens, Legitimacy, Adaptation, and Resilience in Ecosystem Management, 18 ECOLOGY \& SoC'Y, no. 1, 2013, at art. 3, available at http://www.ecologyandsociety .org/vol18/iss1/art3/ (examining theories of legitimacy in the context of adaptive management).

168. See, e.g., Susskind et al., supra note 163, at 4-5 (explicitly expecting progress toward ecological improvement after thirteen years of adaptive management efforts in Glen Canyon).

169. At this point, it is necessary to distinguish agency-based adaptive management, which is what this Article focuses on, from collaborative adaptive management, which purposely involves stakeholders in every aspect of adaptive management decisionmaking. Public participation—or, more precisely, stakeholder participation-is far broader and more continuous in collaborative adaptive management. As a result, additional procedures are recommended to prevent the 
again that many proponents of adaptive management deem public participation to be critical to the project's success. ${ }^{170}$ Thus, the issue of public participation in agency adaptive management should not be framed in terms of whether the public gets to participate in the agency's decisionmaking, but rather when. Public input for every agency adjustment to an adaptive management project or management plan would undermine the agency's ability to implement the lessons it learns in real time and bog down the implementation of adaptive management in the various processes of public participation (notice and comment, collaborative decisionmaking, judicial review), potentially derailing the whole project. As a result, in administrative law terms, these adjustments to a preexisting adaptive management plan should not be considered agency "actions" that trigger public participation requirements.

Nevertheless, formulation of the plan itself is clearly an adaptive management moment that lends itself to public input. Similarly, adaptive management's requirement that agencies engage in periodic evaluations of their progress toward preidentified goals, and hence that they periodically comprehensively adjust the management measures that they are employing, provides additional perfect moments for recurring, rather than continual, public participation.

By focusing on adaptive management as an iterative process, amendments to administrative law that insist that agencies engage in proper adaptive management, rather than $\mathrm{a} / \mathrm{m}$ lite, could actually increase public participation in adaptive management exercises by providing multiple (but punctuated) opportunities for public involvement as the project evolves over time. Rather than forcing agencies who implement adaptive management (or, rather, a/m lite) to delineate the full range of administrative discretion all at once, reformed procedures would require agencies to periodically evaluate and adjust their adaptive management projects and management measures, subject to public notice and comment. The length of the period between comprehensive reevaluations could vary by context, but in most cases should be no longer than five years. In between, the agency's implementation of its adaptive management plan would be, essentially, "hands off"-although public reporting requirements at

collaboration from bogging down or from becoming dominated by one perspective. See Susskind et al., supra note 163, at 30-54 (discussing these procedural "best practices" in the context of the Glen Canyon Adaptive Management Program).

170. See Susskind \& Secunda, supra note 18, at 162-63, 164 (arguing that "ongoing and meaningful" participation by all relevant stakeholders was critical to the improvement and success of the EPA's Project XL). 
regular intervals could both facilitate continual public monitoring and provide a basis for emergency intervention.

\section{Judicial Review}

As with public participation, the question regarding judicial review of agency adaptive management is not a question of whether there should be judicial review, but rather when. In current APA terms, not every agency action in an adaptive management project should be considered "final agency action" subject to judicial review. "Dial adjustments" in accordance with an adaptive management plan that has itself been subject to judicial review do not, themselves, need to be subject to further judicial review.

As a result, the availability of judicial review of adaptive management should largely track the availability of public participation. Judicial review thus would be cyclical, generally available only during the project-review phase and as part of the formulation of the next plan. In other words, judicial review should be available after the agency has summarized and reviewed its monitoring data and formulated-subject to public notice and public participation-its adaptive management plan for the next cycle of implementation. Review of the adaptive management plan would be based on existing standards of administrative judicial review: conformance with administrative procedural requirements; compliance with substantive statutory requirements (especially with respect to management goals); compliance with prior monitoring plans; and the reasonableness of the new adaptive management plan in light of prior monitoring, best available science, or other relevant data and overall management goals.

Of course, there is always the possibility that an agency's implementation of its adaptive management plan will go horribly awry. It may just be, for example, that despite the agency's "best guess" at how to proceed, the complex system does not respond as expectedindeed, it may instead respond in a way that puts the entire system at risk. Alternatively, emergency or unforeseen circumstances may render an agency's existing adaptive management plan moot or futile. For example, the 2008 housing and financial crisis changed various aspects of the real estate, banking, and securities systems throughout the world and was deemed by many to warrant emergency intervention. ${ }^{171}$ In the

171. See Lawrence G. Baxter, Betting Big: Value, Caution and Accountability in an Era of Large Banks and Complex Finance, 31 REV. BANKING \& FIN. L. 765, 852-68 (2012) (assessing causes of the financial crisis including failures in regulation); FIN. CRISIS INQUIRY COMM'N, THE 
realm of natural resources management, in contrast, climate change is likely to increasingly require the overhaul of overall management goals for particular species and ecosystems. ${ }^{172}$ Finally, as in any administrative law context, the agency may simply fail to do any of what it is supposed to be doing, effectively abandoning its adaptive management plan.

As a result, the administrative law governing agency adaptive management needs an "escape valve"-a means of allowing outside intervention (most likely in the form of a judicial injunction) or an abrupt change of course within the agency itself when adaptive management projects are going badly awry or when unforeseen emergencies arise. Of course, if not tightly controlled, this escape valve runs the risk of undermining the basic purpose of designing a special administrative law for adaptive management by allowing discontented litigants to challenge the agency's implementation of its adaptive management plan at any point in the implementation period. ${ }^{173}$ To avoid this outcome, legislatures should enact strict criteria for emergency intervention, especially for outsider challenges in court, and make it clear in the statute itself that these criteria are to be strictly construed against court intervention. Formulating strict standards that can still apply broadly to a variety of different types of agencies, though, will be difficult, regardless of the care in drafting. Hence, a heavy burden of proof (either beyond a reasonable doubt or clear and convincing evidence) and strict standard for judicial action (strict scrutiny) can best effectuate the goal of keeping the opportunity for emergency intervention narrow. Nevertheless, out of deference to the

FINANCIAL CRISIS INQUIRY REPORT (2011), available at http://www.gpo.gov/fdsys/pkg/GPOFCIC/pdf/GPO-FCIC.pdf (same); Iman Anabtawi \& Steven L. Schwarcz, Regulating Systemic Risk: Towards an Analytical Framework, 86 NoTRE DAME L. REV. 1349, 1352 (2011) (same); Manuel A. Utset, Complex Financial Institutions and Systemic Risk, 45 GA. L. REV. 779 (2011) (same).

172. See, e.g., Susskind et al., supra note 163, at 28 (noting that, in the Glen Canyon system, "[t]he precarious state of the downriver ecology is particularly disconcerting because anticipated stressors, such as climate change, are likely to strain the ecosystem even further" and that studies indicate that the Colorado River and its reservoirs could dry up entirely by 2057); see also Mark Squillace \& Alexander Hood, NEPA, Climate Change, and Public Lands Decision Making, 42 ENVTL. L. 469, 474 (2012) (proposing that adaptive management become a required approach under NEPA as a result of climate change); Rhett B. Larson, Innovation and International Commons: The Case of Desalination Under International Law, 2012 UTAH L. REV. 759, 800 ("Adaptive management has become a central feature of climate change policy debates, as policymakers must respond to a changing environment and a better understanding of climate change through improved modeling."); Craig, supra note 49, at 15, 17, 39, 65-67 (repeatedly positing adaptive management as a salutary tool for climate change adaptation).

173. For example, Susskind et al. have described the debilitating effects of continual legal challenges to the Glen Canyon Adaptive Management Program. Susskind et al., supra note 163, at $26-27$. 
agency's expertise, slightly less stringent criteria should apply to the agency's own determination that it needs to change course. Again, however, the statutory presumption should be against abandoning the current adaptive management plan midcourse unless there are clear and convincing reasons for doing so.

\section{Finality}

Unlike traditional agency decisionmaking in rulemaking and adjudication, adaptive management decisionmaking by its very nature is not-or at least not immediately-final. The question, therefore, is how to balance adaptive management's fluidity and flexibility with the law's demand for some sense of finality. As a practical matter, "[a]daptive management cannot, of course, be constantly changing; it is public regulation that must satisfy constitutional requirements of substantive and procedural due process." 174 These concerns are particularly acute when an agency's implementation of adaptive management affects not just its own direct regulatory or management actions but also the conditions and requirements imposed on regulated entities. ${ }^{175}$ Conversely, adaptive management does not lend itself to the one-time "final finality" that is the goal of both administrative process and American law more generally. ${ }^{176}$

Fortunately, adaptive management readily lends itself to periodic "reset points." Specifically, adaptive management is already conceived of as an iterative process where progress depends on these reflective "pause points" that allow or require the managing entityhere, the administrative agency - to evaluate past actions and reassess its future course. These pause points provide apt moments for the public processes of administrative law to intervene in an ongoing process of adaptive management, satisfying needs for temporary certainty regarding the agency's next course of action as well as allowing for meaningful public participation and judicial review.

It is important to recognize, however, that adaptive management temporally separates two aspects of agency finality that are generally united in front-end, binary agency decisionmaking. The first aspect of finality is the completion of the decisionmaking process itself - the end of a rulemaking, the order in an agency adjudication, the

174. Tarlock, supra note 136 , at 1141 ; see also Ruhl \& Fischman, supra note 6 , at 478 (acknowledging "that the scope of adaptive management is not boundless").

175. See Ruhl \& Fischman, supra note 6, at 477 ("Private regulated interests have expressed concerns about the capacity of adaptive management to add continually to the conditions imposed by resource development authorizations without the security of finality.").

176. See id. at 429 (describing adaptive management as evolutionary and iterative). 
final decree in court after the last possibility of appeal has expired. Administrative law for adaptive management preserves this sense of finality by focusing on each round of the agency's adaptive management plan as a legally final "event": absent the emergencies described above, at the end of the judicial review period, the adaptive management plan will govern the management measure or project at issue for the time period designated-generally one to five years, but perhaps longer for larger and more complex management activities.

However, by definition, each iteration of an adaptive management plan probably will not be the substantively final implementation of overall legislative intent or policy goals, which compose the second aspect of finality in agencies' traditional decisions. When the FDA decides to approve a new drug for human use, it has definitively decided-at least based on the evidence currently available - that the drug meets the substantive-law requirements for efficacy and safety. When the U.S. Army Corps of Engineers decides to dredge a harbor, it has definitively decided that the dredging will advance the Rivers and Harbors Act's goal of improving navigation. Indeed, this alignment of the agency's final decision and the statute's substantive goals is the basis of arbitrary and capricious review in administrative law.

Judicial review under the arbitrary and capricious standard, however, has always suggested that there is a lurking issue in much agency decisionmaking regarding how confident an agency has to be that its proposed implementation of a statute will actually accomplish what the agency thinks it will and hence advance the legislature's overall goals and purposes. For example, under the federal MagnusonStevens Fishery Conservation and Management Act, ${ }^{177}$ regional Fishery Management Councils must establish measures designed to recover a "depleted" fishery, ${ }^{178}$ and these measures often include fishing quotas. The U.S. Court of Appeals found unreasonable a fishing quota that had only an $18 \%$ chance of recovering the relevant fishery, commenting that "[o]nly in Superman Comics' Bizarro world, where reality is turned upside down, could the Service reasonably conclude that a measure that is at least four times as likely to fail as to succeed offers a 'fairly high level of confidence.' "179 More generally, clashes over this "confidence" issue may be one indication that adaptive management may be a better course for the agency decisions at issue.

177. 16 U.S.C. $\S \S 1801-83$ (2012).

178. See id. $\S 1851$ (a)(1) (requiring measures to prevent overfishing).

179. Natural Res. Def. Council, Inc. v. Daley, 209 F.3d 747, 754 (D.C. Cir. 2000). 
A special legal track for adaptive management would therefore be more transparent than current administrative law regarding the agency's ability to meet (and its process for achieving) legislative goals, at least to the extent that the adaptive management plans required in the proposed new track lay bare the agency's degree of uncertainty regarding specific management measures and its plans for actively improving the efficacy of its management "best guesses." Nevertheless, substantive finality (or at least the illusion of substantive finality) is purposely put off until some point in the future, if it can be "finally final" at all. This poses two implications for administrative law. First, as will be discussed in the next Section, administrative law for adaptive management needs to provide a procedure whereby an agency can take a project off the adaptive management track-most likely because the agency has resolved, through trial and error, all or most of the uncertainties that were making management difficult, in situations where continual change is not a complicating factor. Second, in judicial review of adaptive management plans, arbitrary and capricious review cannot be based on the agency's certainty of achieving overall management goals in the next round of implementation. Instead, judicial review should evaluate the reasonableness of the adaptive management plan in making progress toward those overall management goals in terms of resolving recognized uncertainties in the management problem, improving basic information regarding the system's function and complexity, and measuring ongoing changes to the system.

In other words, an adaptive management plan should be judged adequately "final" if it proposes a well-defined and reasonable experiment that will result in progress-theory confirmation or falsification, increased knowledge of basic system features that are relevant to the management objective, and so on-toward the overall legislative goal. And, indeed, this is how most advocates of adaptive management think about finality in this context. ${ }^{180}$ Administrative law can further the improved use of adaptive management by doing the same.

\section{B. Designing Administrative Law Specifically for Adaptive Management}

Beyond the traditional administrative law values,
commentators who have argued for experiments in adaptive

180. See, e.g., Susskind et al., supra note 163, at 24-25 (evaluating the Glen Canyon Adaptive Management Program in terms of progress toward its announced goals). 
management have agreed that certain features are critical. These features should be incorporated into any legislation explicitly allowing for adaptive management. They include (1) criteria for defining what sorts of projects or management measures qualify for the special legislation;181 (2) definition of project or management-measure goals and their relative priorities; ${ }^{182}$ and (3) objective monitoring of the project or management measure implementing adaptive management, ${ }^{183}$ with progress measured against concrete standards. ${ }^{184}$ To achieve the goal of allowing agencies to engage in true adaptive management, moreover, agency decisionmaking following the adaptive management track should generally be free of additional external procedural requirements. ${ }^{185}$ In the federal system, these include the National Environmental Policy Act ("NEPA") and its requirement for an Environmental Impact Statement;"186 the ESA's "jeopardy" consultations and habitat conservation plan requirements; ${ }^{187}$ and multiple rounds of regulatory impact analyses, including cost-benefit analyses. Finally, the new administrative procedures should allow agencies to end the adaptive management process when the agency's implementation measures achieve stable results that meet a predetermined goal or when it becomes clear that adaptive management is not working. This Section describes in turn each of these features of the proposed new Model Adaptive Management Procedure Act ("MAMPA").

181. See Susskind \& Secunda, supra note 18, at 166 (suggesting five criteria for proposed projects).

182. Ruhl \& Fischman, supra note 6, at 424, 472, 482; see also Comm. ON ENDANGERED \& Threatened Fishes In the Klamath River Basin, supra note 20, at 332-335; cf. Susskind et al., supra note 163, at 6, 25 (criticizing the lack of clearly stated goals for the Glen Canyon Dam project).

183. Ruhl \& Fischman, supra note 6, at 424; see also COMM. ON ENDANGERED \& THREATENED FISHES IN THE KLAMATH RIVER BASIN, supra note 20, at 332-35; Susskind \& Secunda, supra note 18 , at $166,169,170$.

184. Ruhl \& Fischman, supra note 6, at 482; see also COMM. ON ENDANGERED \& THREATENED FISHES IN THE KLAMATH RIVER BASIN, supra note 20, at 332-35; Susskind \& Secunda, supra note 18, at 164-65, 170 (advocating the use of ISO environmental management standards as a benchmark for assessing the success of Project XL adaptive management proposals and arguing that continuous evaluation is "crucial").

185. See, e.g., Schultz \& Nie, supra note 38, at 444 (noting that compliance with other procedural requirements, especially NEPA, poses a real challenge to implementing adaptive management).

186. See 42 U.S.C. $§ 4332(C)$ (2012) (requiring all federal agencies to produce environmentalimpact reports for major federal actions).

187. See 16 U.S.C. $\S \S 1536(a), 1539$ (a) (requiring federal agencies to consult with the Secretary of the Interior or Secretary of Commerce regarding projects that could jeopardize endangered species and allowing the Secretary to take actions necessary to maintain populations). 
1. Getting on the Adaptive Management Track: Three Pathways

Establishing an alternative set of administrative law procedures for adaptive management-what we have been calling the adaptive management track-necessarily creates the issue of how to determine whether an agency can use the alternative track for a particular decisionmaking process. This question, in turn, depends upon whether the relevant legislature has specified what the agency is to do or whether the choice is the agency's own, resulting in three potential situations regarding the agency's ability to use the adaptive management track. Section 2 of the MAMPA addresses these three situations.

First, the legislature might definitively require an agency to use adaptive management for a specific management context or set of management decisions. Second, and conversely, the legislature might expressly forbid an agency from using adaptive management for particular kinds of decisions or for any decision. In either of these two cases, the legislature's pronouncement would be final, and the roles of the agency and courts in evaluating the propriety of the adaptive management track would be minimal, particularly when the legislature has expressed itself clearly.

Third, the legislature might leave the choice of whether to use the adaptive management track to the agency, either expressly or through statutory silence on the issue. We generally deem statutory silence and express statutory delegation of the decision to choose the adaptive management track to the agency as legally equivalent, which both (1) pragmatically avoids requiring the legislature to amend all prior statutes to address the adaptive management possibility before an agency can opt into the adaptive management track and (2) acknowledges agencies' potentially greater expertise regarding the issue of when adaptive management would be desirable and appropriate substantively and contextually. However, we also acknowledge that requiring the legislature to give the agency express permission to use the adaptive management track would eliminate several threshold legal issues, such as evaluating whether adaptive management is appropriate for the management project at issue, an option that states in particular might find attractive.

When an agency has the option of deciding whether to pursue the adaptive management track, the MAMPA requires the agency to make a positive decision to do so through standard notice-and-comment (informal) rulemaking. In so doing, the MAMPA constructs standard administrative procedures as the default rule: federal agencies, for example, would follow the APA unless Congress clearly instructs 
otherwise or Congress has allowed the agency the choice (or is silent on the issue) and the agency decides to pursue the adaptive management track. This default preserves administrative law's status quo and hence minimizes overall disruption when a legislature decides to introduce the adaptive management track. The default rule also reflects our sense that use of the adaptive management track will in fact be less frequent and less appropriate than use of standard administrative procedures in most agency decisionmaking.

In making a decision to use the adaptive management track, the agency must demonstrate, based on "the best evidence available," that the project or management activity at issue is appropriate for adaptive management, using the factors and considerations that we identified in Part II. The "best evidence available" standard is intended to prevent courts from requiring agencies to have perfect information regarding the suitability of adaptive management, while the factors are intended to ensure that the agency can nevertheless demonstrate a good fit between the project or management activity and the basic goals and constraints of adaptive management.

As specified in Section 6 of the MAMPA, the agency's decision to use the adaptive management track, expressed in a final rule, is judicially reviewable but subject to a ninety-day statute of limitations. The short statute of limitations limits the time delay between an agency's decision to use adaptive management and its ability to actually begin the adaptive management process if there are no challenges to the propriety of its decision. If judicial review is sought, however, the reviewing court (we propose for federal agencies the U.S. Courts of Appeals) can assess both the legislature's intent regarding adaptive management and the propriety-under standard arbitrary and capricious review-of the agency's decision to use adaptive management for the particular project or management activity at issue. Judicial review for alleged procedural and constitutional violations is also available.

Finally, an agency's decision to use the adaptive management track would be subject to all other applicable procedural and evaluative requirements that would normally apply to agency rulemaking under the appropriate state or federal laws. For federal agencies, for example, the agency's initial decision to use the adaptive management track could thus be subject to various cost-benefit analyses ${ }^{188}$ and review by

188. E.g., Unfunded Mandates Reform Act, 2 U.S.C. $\S \S 1532,1535$ (2012) (requiring costbenefit analyses for rulemaking resulting in spending of $\$ 100$ million or more in the government and private sectors in a given year and requiring consideration of reasonable alternatives). 
the Office of Management and Budget, ${ }^{189}$ various regulatory-impact analyses, ${ }^{190}$ environmental impact assessment requirements under NEPA, ${ }^{191}$ or consultation requirements under the ESA. ${ }^{192}$ Subjecting the agency's decision to these traditional requirements both reflects the MAMPA's provision that normal administrative law procedures remain the default set of requirements and ensures at the outset that the agency's decision to change procedural tracks will not in and of itself violate existing statutory and executive limitations on agency actions.

\section{Formulating the Initial Adaptive Management Plan: Goals, Monitoring, and Standards}

Once an agency's project or management action, or category of projects or management actions, is subject to the adaptive management track, the first step is for the agency to adopt its initial adaptive management plan. Section 3 of the MAMPA addresses this step.

In order to avoid the re-creation of $\mathrm{a} / \mathrm{m}$ lite, the MAMPA subjects agencies to a rigorous planning requirement that details the necessary elements of true adaptive management. First, as adaptive management theory demands, the agency must identify specific management goals and objectives, both for the system overall and for its initial management measures. These goals and objectives provide the overall measures against which both the agency and the courts can measure progress in the adaptive management process.

Second, the agency must identify, to the extent possible, potential threats to its management goals and potential stressors and perturbations to the managed system. Identifying these threats, stressors, and perturbations from the beginning will help the agency to define and adjust its management measures. Doing so can also help to define potential events that might require abrupt changes in the

189. E.g., Regulatory Planning and Review, Exec. Order No. 12866, 58 Fed. Reg. 51,735 (Sept. 30 , 1993) (requiring federal agencies engaged in "significant" regulatory action to submit their proposed rules to the Office of Management and Budget for review).

190. E.g., Regulatory Flexibility Act, 5 U.S.C. $§ \S 601-12$ (2012) (requiring a federal agency to prepare a regulatory flexibility analysis of any rule subject to notice-and-comment rulemaking requirements under the APA or any other statute unless the agency certifies that the rule will not have a significant economic impact on a substantial number of small entities); Consultation and Coordination with Indian Tribal Governments, Exec. Order No. 13175, 65 Fed. Reg. 67,249 (Nov. 6,2000 ) (requiring federal agencies to develop an accountable process to ensure "meaningful and timely input by tribal officials in the development of regulatory policies that have tribal implications"); Federalism, Exec. Order No. 13132, 64 Fed. Reg. 43,255 (Aug. 4, 1999) (requiring federal agencies to develop an accountable process to ensure "meaningful and timely input by State and local officials in the development of regulatory policies that have federalism implications").

191. 42 U.S.C. $\S 4332(C)(2012)$.

192. 16 U.S.C. $§ 1536(a)(2012)$. 
agency's adaptive management plan or that might even render the system no longer amenable to adaptive management in general.

Third, the agency must identify relevant indicators in the system, both generally and for this round's monitoring plan. Indicators are the system components that the agency will monitor throughout the adaptive management process to gauge its progress toward its management goals. As a result, the indicators chosen must give the agency an ability to comprehensively and meaningfully assess the system and how it is changing in light of the management objectives.

Fourth, the agency must develop a monitoring plan. The monitoring plan must be defensible under the best practices of the professional discipline most relevant to the project or management action (for example, a forest-management action would turn to biology). It must also use a standardized and accepted methodology that the agency implements consistently so that the agency can compare the resulting data over time. In addition, the agency must provide for the periodic release of monitoring data to the general public in a comprehensible and usable form. The MAMPA suggests that such public reports on the agency's activities be spaced no more than six months apart, although we acknowledge that longer or shorter periods might be appropriate for different kinds of agency activities. The legislature, of course, remains free to specify different times for different agency management situations.

Fifth, and perhaps most importantly, the agency must identify in its initial adaptive management plan changes in indicator statuses that are relevant to evaluating its progress toward the identified management objectives. ${ }^{193}$ Specifically, the agency must describe changes in the indicators that would suggest that either the system is moving in a positive direction (i.e., toward achieving management goals) or that the system is moving in a negative direction. As part of this process, the agency must also identify means by which it can determine whether the changes in the indicators are in fact caused by its management measures or by other factors (or some combination). Finally, the agency should identify changes in system indicators, individually and collectively, so negative that they counsel in favor of aborting the current management plan. These "abort indicators" will become the primary measures through which either the agency can justify abrupt changes in its adaptive management plan or the general

193. See Schultz \& Nie, supra note 38, at 444-45, 455-64, 469-91 (advocating the use of "triggers" in agency implementation in adaptive management for reasons similar to those that prompt us to require the agency to specify various criteria for evaluating its actions and for aborting current management activities). 
public can justify emergency intervention; they also provide one measure through which the agency can reassess whether adaptive management was an appropriate decisionmaking process in the first place.

The agency adopts its initial adaptive management plan-and every subsequent adaptive management plan-through notice-andcomment rulemaking. As such, the process of formulating each adaptive management plan is subject to public notice, comment, and hearings when appropriate, just as under traditional administrative law. The MAMPA expands upon this traditional public participation, however, by requiring that the agency also actively invite more public involvement in the plan's formulation through representatives of interest groups and stakeholders. The requirement, specifically, is that the agency make reasonable efforts to involve and accommodate these groups. However, the Act also leaves the agency with considerable discretion to limit the number of participants to a level that will be both manageable and helpful. The intention, as adaptive management theory recommends, is for agencies to involve interested stakeholders, through their representatives, in plan formulation earlier in the process than standard notice-and-comment rulemaking would allow.

The agency's initial adaptive management plan is subject to fairly standard judicial review, but with two innovations to current APA requirements. First, judicial review is subject to a short (thirty-day) statute of limitations. This short window is intended both to recognize that increased stakeholder participation in the planning process will ideally eliminate many conflicts, reducing the need for extensive judicial review, and to encourage stakeholders and the interested public to keep a close eye on agency adaptive management efforts. Second, courts engaged in judicial review of agency adaptive management plans now have, through the MAMPA's section 3 requirements, a substantial structural guide for ensuring that agencies are engaged in "proper" adaptive management, because failure to include or adequately explain any required plan element would be grounds for remanding the entire plan to the agency. In other words, the MAMPA teaches courts how agencies should be implementing proper adaptive management.

One final aspect of the procedures for the initial adaptive management plan is worth noting. The MAMPA generally exempts agency adaptive management plans from the substantive and procedural requirements of any statutes, regulations, or executive orders other than the statute that authorized the agency to engage in the relevant management activities in the first place (but, as explained above, not the initial decision to choose the adaptive management track). As such, once an agency is on the adaptive management track, 
it is free from confining and occasionally derailing ongoing procedural requirements-including but not limited to NEPA environmental analysis requirements, ESA consultation requirements, and OMB review and associated cost-benefit analysis requirements-unless the agency's authorizing statute provides otherwise. This exemption is intended to provide agencies with an incentive for engaging in the rigorous process of adaptive management planning and implementation. Notably, however, nothing in the MAMPA prohibits agencies from following these requirements voluntarily, and the relevant legislature can always specifically require continued compliance for particular agency adaptive management processes.

\section{The Implementation Phase and Emergency Interventions}

In one of its most important innovations for administrative procedure, the MAMPA specifies that once an agency is actually implementing an adaptive management plan, no judicial review of its interim decisions is available unless emergency intervention is appropriate. In more traditional administrative law terms, the implementation phase is considered "committed to agency discretion by law," with limited exceptions. The MAMPA underscores this commitment to agency discretion by specifying that, in general, challengers will not be entitled to their costs or to attorney fee awards in lawsuits filed during the implementation period even if they are successful, removing one incentive for implementation period litigation. As has been discussed, this freedom from judicial review during the implementation phase is necessary for true adaptive management to occur. However, the elimination of judicial review that the MAMPA provides also offers agencies an additional incentive for using the adaptive management track when it is appropriate.

The general unreviewability of the implementation phase under the MAMPA gives agencies considerable discretion to pursue adaptive management, correcting one of the most important limitations of conventional administrative law for adaptive management. Nevertheless, we acknowledge that this increase in agency discretion will make many people and interest groups uncomfortable. ${ }^{194}$ To

194. See id. at 444; see also Neil Green Nylen, Note, To Achieve Biodiversity Goals, the New Forest Service Planning Rule Needs Effective Mandates for Best Available Science and Adaptive Management, 38 ECOLOGY L.Q. 241, 245 n.22 (2011) ("This need to balance structure with discretion is an across-the-board concern in administrative law." (citation omitted)). Notably, however, Emily Hammond and Dave Markell have recently examined how agencies can legitimize their behavior even in the absence of judicial review-what they term "legitimacy from the insideout." See generally Hammond \& Markell, supra note 117. This Article accepts their premise that 
mitigate this discomfort while still providing agencies with what we consider necessary additional discretion, the MAMPA provides mechanisms whereby interested members of the public can keep an eye on what the agency is doing during the implementation phase and can intervene in true emergencies or if the agency has completely abandoned the project. First, the agency must provide the general public with its monitoring data in an understandable and usable form at least every six months. Second, the agency must report to the general public at least once per year regarding how it is implementing its adaptive management plan (including adjustments that it has made to its management measures). If the agency fails to provide monitoring data or required reports within two months of their due dates, members of the public can sue for the limited purpose of compelling production. Third, either members of the public or the agency itself can abort the current adaptive management plan under two circumstances: (1) the system achieves the abort indicator statuses designated in the management plan; or (2) an unanticipated severe disturbance occurs in the system, such as an unanticipated natural disaster, economic collapse, or act of war or terrorism. Finally, if the agency clearly and completely abandons its adaptive management plan (as narrowly defined in the MAMPA's judicial review provisions in section 6), members of the public can sue the agency to compel compliance or to force the agency to formally abandon the adaptive management track. However, if the court dismisses any such lawsuit because the agency actually is acting, the agency is entitled to its costs and attorney fees. This provision of MAMPA is intended to underscore the narrowly tailored nature of the "abandonment" cause of action.

As part of their adaptive management plans, agencies must identify abort indicators (MAMPA sections 3(B), 4(B)). Abort indicators are a specified set of monitored statuses that, if they occur either collectively or individually, signal to the agency that its management measures are taking the system grossly off any path toward achieving its management goals. During the planning-period rulemaking, the agency must explain and justify the abort indicators it chooses, and these abort indicators are subject to judicial review. As a result, achievement of the abort indicators should signal to both the agency and the general public that the current adaptive management plan should be terminated-unless, as the MAMPA makes clear, the agency can attribute those indicator statuses to the occurrence of an

agency legitimacy can exist even in the absence of judicial review, and we have structured our vision of agency adaptive management plans to help build such legitimacy during the implementation phase, despite increased agency discretion. 
unexpected and temporary perturbation to the system whose effects are not expected to be permanent or long lasting.

Under sections $3(\mathrm{C})(1), 4(\mathrm{C})(1)$, and $5(\mathrm{~B})$ of the MAMPA, if the abort indicators are achieved, the agency can terminate the management plan simply by giving notice in the Federal Register (or the state equivalent) and waiting thirty days; no rulemaking is required for termination, although it will be required for the new adaptive management plan, which is subject to the provisions of section 4 . Alternatively, under section 5(D), members of the public can file a mandamus action in federal district court or the designated state court (subject to any jurisdictional limitations such as standing and the traditional requirements and limitations governing mandamus). Both the agency, if its decision is challenged as allowed in section 6, and mandamus petitioners must prove the case for termination by clear and convincing evidence, an evidentiary standard imposed to better ensure that termination is in fact warranted. Mandamus petitioners are also subject to additional procedural requirements to ensure that such court actions are rare and do not interfere with the agency's own decision to terminate.

Given that the agency must identify "expected" conditions for termination of the adaptive management plan through the abort indicators, we purposely designed the MAMPA's provision for "true" emergency termination in sections $5(\mathrm{C})$ and $5(\mathrm{E})$ to be extremely limited; moreover, the statute instructs the courts to narrowly interpret these provisions. To terminate agency implementation because of an emergency, either the agency or members of the public petitioning for mandamus must show that (1) a severe disturbance to the system occurred, (2) the adaptive management plan did not anticipate the disturbance, and (3) the disturbance fundamentally altered the information or system status that formed the basis of the adaptive management plan. Again, the agency can terminate its implementation merely by publishing notice in the Federal Register and waiting thirty days, but its decision is subject to judicial review under section 6 . In addition, again, both the agency (if its decision is challenged) and the mandamus petitioners must prove their cases by clear and convincing evidence, and mandamus petitioners are subject to additional requirements intended to limit their ability to interfere with the agency's own decisionmaking. 
4. Resetting at the Pause Point: Review, Evaluation, and the Next Round of Adaptive Management

The agency's implementation of its current adaptive management plan will eventually end, at which point the agency proceeds to the steps of evaluating the data gathered, reviewing its management options, and proposing a new adaptive management plan for the next round of management-measure implementation. The MAMPA envisions three "natural" termination triggers for ending the implementation period, spelled out in sections 3(C) and 4(C). First, as discussed in the previous Section, the agency should terminate its adaptive management plan when the system achieves the abort indicators. Second, and conversely, the system might achieve the plan's "finished indicators." Like the abort indicators, finished indicators are specific statuses identified in the adaptive management plan that the monitored indicators might achieve during the course of the implementation period. However, unlike abort indicators, finished indicators are signals that the agency's current management measures have done their job-assuming that no other cause explains their achievement-and that it is time for the agency to make additional progress toward its ultimate management goals. Third, the implementation period might end simply as a result of the passage of time. In the absence of an express, legislatively imposed time limit on the implementation period, the MAMPA requires the agency to choose and justify an appropriate length of time as part of the adaptive management plan, and that time limit would govern termination. However, the MAMPA also imposes a default outer limit of five years for any implementation period.

Through section 4, the MAMPA presumes that the agency will continue through successive rounds of adaptive management plans. The agency adopts subsequent plans, like the first, through notice-andcomment rulemaking, subject to the same additional public participation requirements, substantive plan-component requirements, and judicial review. However, after the first round of implementing adaptive management, the agency must also (1) explain what it has learned about managing the system, both in the immediately previous implementation period and over the entire adaptive management process; (2) adopt new management measures based on that evaluation; and (3) explain any and all changes to the adaptive management plan based on new information, changes to the system or its components, or changes to the law that the agency is implementing.

Once the agency adopts a new adaptive management plan (and survives any judicial review), it proceeds into a new implementation 
period. It continues through rounds of planning and implementation until it has reason and the legal ability to remove the project, management action, or category of projects or management actions, from the adaptive management track.

\section{Getting Off the Adaptive Management Track Once on It}

Some agency management situations may be so subject to continual change that there is no reason for the agency to ever take its management action off the adaptive management track. In these situations, adaptive management becomes the single best means of managing the system. Public lands managers, for example, may well find that perpetual adaptive management best enables them to cope with the continual and escalating impacts of climate change on the relevant ecosystems. And, as we have already discussed, the Federal Reserve (although outside the standard administrative law system) is effectively perpetually pursuing adaptive management with respect to interest rates.

For other management situations, though, the initial problems, such as lack of basic information about the system or how it responds to various management measures, can actually be solved through adaptive management, allowing the agency to stabilize both the system and its management activities. At that point, the agency may find that the adaptive management track is no longer necessary or helpful.

Alternatively, after a few rounds of adaptive management, the agency may find that the system or the management problem is not, after all, amenable to adaptive management. If it was the agency that decided to pursue the adaptive management track in the first place, and it has made a good faith effort to use adaptive management, albeit to little avail, it should have the option to remove its project or activity from the adaptive management track.

Section 4 of the MAMPA outlines four situations in which leaving the adaptive management track is appropriate. First, Congress or the relevant state legislature may have intervened since the agency began its adaptive management process and ordered the agency to take its project or management action off the adaptive management track. Agencies must, of course, comply with these new legislative mandates.

Second, even if Congress or the state legislature required the agency to use adaptive management, it may also have specified when the agency would be "done." If the agency's adaptively refined management measures have achieved the legislative criteria for leaving the adaptive management track, the agency can-and possibly mustdo so. 
Third, even when an agency chose the adaptive management track, it may be able to identify clear criteria for when the adaptive management process would have stably achieved all management goals. If the adaptive management process brings the agency to the point where its management measures meet these criteria, and if the agency can now stably manage the system and maintain the applicable management goals, it may conclude that the adaptive management track has served its purpose and that it can now operate effectively through traditional front-loaded administrative rulemaking and planning. The MAMPA allows agencies in this situation to leave the adaptive management track.

Finally, an agency that initially showed that its management situation fit the criteria in section 2 of the MAMPA for entering the adaptive management track may find that, in reality, adaptive management is not working after all. The MAMPA effectively requires that the agency make a good faith effort at using adaptive management. However, if the agency can show that (1) its reasonable management measures repeatedly take the system to the point where the abort indicators are achieved, (2) the system has changed significantly since the agency decided to pursue the adaptive management track, or (3) new information gathered in the process of adaptive management significantly undermines the agency's initial conclusion that adaptive management is appropriate, then the agency can leave the adaptive management track.

Section 4(A) of the MAMPA requires the agency to make and justify through notice-and-comment rulemaking its decision to take a project or management action off the adaptive management track. The final rule is subject to fairly standard judicial review requirements.

\section{CONCLUSION}

For two reasons, experiments with adaptive management in the field have thus far failed to live up to the promise of adaptive management in theory. One is that adaptive management is not a good fit for many, or even most, policy management problems. The first wave of adaptive management scholarship was perhaps too optimistic in this regard, offering up adaptive management as a panacea to the intractability of front-end-style agency decisionmaking without carefully thinking through its own limitations. Swept up in this euphoria, policy managers may have applied adaptive management too aggressively and in ill-suited contexts, thus setting it up for failure. More recently, however, these lessons learned have led to a 
reexamination of adaptive management theory to refine the contextual, practical, and normative conditions under which its use is appropriate.

Accepting those conditions as the new starting point for applying adaptive management, we have examined the second reason for adaptive management failure - the front-end-focused requirements of conventional administrative procedure. Adaptive management and conventional administrative procedure form a classic square-peg, round-hole mismatch that has captured the attention of many adaptive management theorists. The now widely held perception is that three deeply rooted values of administrative procedure-public participation, judicial review, and finality-combine in conventional administrative law to erect a nearly impenetrable barrier to effective adaptive management. These values are perfectly appropriate for administrative procedure, and we do not propose abandoning them to make adaptive management possible. However, neither do we believe adaptive management must be stuck forever in $\mathrm{a} / \mathrm{m}$ lite mode in order to preserve administrative procedure's values. Rather, we follow through on suggestions that we and others have made for a specialized adaptive management track in administrative procedure that balances the needs of adaptive management with the values of administrative law.

Our proposed adaptive management track is the first detailed blueprint for a new legal structure to match adaptive management's decisionmaking structure. Recognizing that some tradeoffs are inevitable, we have sought to retain the core values of administrative law to the maximum extent possible in a procedural framework that allows agencies to engage in true adaptive management. However, to avoid $\mathrm{a} / \mathrm{m}$ lite, we have simultaneously designed this new track to help ensure that agencies apply adaptive management effectively and only in appropriate settings. Finally, the adaptive management track's processes, standards, and requirements should actively educate judges and the public as to how adaptive management can be as rigorous and transparent as traditional agency decisionmaking.

We have made some tough decisions regarding how to redesign administrative law for adaptive management, and some of our choices may spark debate. We welcome that debate, because we consider our proposed Model Adaptive Management Procedure Act to be an opensource work in progress and have every expectation that it can and will be improved. Indeed, we hope we have persuaded all adaptive management theorists and practitioners and all administrative law theorists and practitioners that they have a stake in the project of designing administrative law for adaptive management, and we hope 
[Vol. 67:1:1

they will consider this Article an invitation to take our blueprint to their drawing boards for more work. ${ }^{195}$

195. We are pleased to be part of a process with that goal in mind, an interdisciplinary workshop effort spearheaded by Professor Barbara Cosens of the University of Idaho and Professor Lance Gunderson of Emory University that has received generous funding from the University of Maryland's Socio-Environmental Synthesis Center (SESYNC). 
VI. APPENDIX

The Model Adaptive Management Procedure ACT

Section 1: Definitions .................................................... 63

Section 2: Agency Projects and Management Actions Subject to the Adaptive Management Procedure Track........... 66

Section 3: $\quad$ Initial Adaptive Management Plan ............................. 68

Section 4: Subsequent Adaptive Management Plans................... 75

Section 5: Termination of Adaptive Management Plan Implementation Because of Emergency Circumstances. 79

Section 6: Judicial Review .................................................... 83

\section{Section 1: Definitions}

(A) "Abort indicators" means indicator statuses identified by the agency in compliance with $\S \S 3(\mathrm{~B})(3)(\mathrm{h})$ and $(5)(\mathrm{d})$ of this Act (and as made applicable to $\S 4(\mathrm{~B})$ ) and which signal that the agency should terminate immediately its current management measures.

(B) "Adaptive management" means a decisionmaking process based on the structured and iterative implementation of management measures, with comprehensive monitoring of relevant system indicators, in the attempt to achieve specific management goals or objectives, reduce uncertainty, or increase knowledge about the system that an agency is charged with managing.

(C) "Adaptive management plan," when used without qualification, refers to an agency plan adopted pursuant to either $\S 3$ or $\S 4$ of this Act.

(D) "Adaptive management track" or "adaptive management procedure track" means the agency procedures and requirements established in Sections 2 through 6 of this Act. 
(E) "Administrative Procedure Act" or "APA" means 5 U.S.C. $\S \S 551-559$, 701-706. [States would substitute the appropriate statute and definition.]

(F) "Agency" means each authority of the Government of the United States [State of ], whether or not it is subject to review by another agency, but does not include:

(1) the President [Governor];

(2) the Congress [legislature];

(3) the courts of the United States or the states;

(4) the governments of the territories or possessions of the United States;

(5) the government of the District of Columbia.

(G) "Complex system" or "system" means a policy-management context in which the relevant social, economic, technological, biological, physical, and environmental components are numerous, diverse, and interrelated; exhibit feedback between each other as conditions change; and adapt to stressors, perturbations, and management measures over time, based at least in part on how other components within the policy-management context respond.

(H) "Finished indicators" means the indicator statuses identified by the agency in compliance with $\S \S 3(\mathrm{~B})(3)(\mathrm{i})$ and (5)(D) of this Act (and as made applicable in $\S 4(\mathrm{~B})$ ) and which identify system responses that have met the goals for the agency's current implementation of management measures.

(I) "Implementation period" means the period in which the agency is implementing an adaptive management plan.

(J) "Management action" or "agency management action" refers to larger-scale agency activity, the purpose of which is to guide a system toward the agency's or legislation's overall management objectives or goals for the system. 
(K) "Management measure" means any specific or smaller-scale agency action taken as part of a management action in order to gather information about the system generally or a system component, test the system's response to a proposed management action, pursue immediate management objectives for the system or one of its components, or reduce risks to or uncertainties about the system or one of its components.

(L) "Person" includes an individual, partnership, corporation, association, or public or private organization other than an agency.

(M) "Perturbation" means an event that disrupts the number, diversity, interrelations, feedback mechanisms, and adaptive capacities of the components of a complex system.

(N) "Project" or "agency project" means a specific agency activity that redesigns, physically alters, or rearranges some or all of the components of a system.

(O) "Rule" means the whole or a part of an agency statement of general or particular applicability and future effect designed to implement, interpret, or prescribe law or policy or describing the organization, procedure, or practice requirements of an agency. "Rule" includes an agency's initial decision to follow the adaptive management track and all adaptive management plans.

(P) "Rulemaking" means the agency process for formulating, amending, or repealing a rule.

(Q) "Stressor" means a social, economic, technological, biological, physical, or environmental condition that acts over time to disrupt the number, diversity, interrelations, feedback mechanisms, or adaptive capacities of the components of a complex system. 
Section 2: Agency Projects and Management Actions Subject to the Adaptive Management Procedure Track

(A) Unless one of the sets of circumstances described below in subsections (C) or (D) is met, an agency must follow the normally applicable procedures of the Administrative Procedure Act [state equivalent statute] for the project or management action or category of projects or management actions at issue. However, if the requirements of subsections (C) or (D) are met, this Act supersedes the Administrative Procedure Act [state equivalent statute] for the project, management action, or category of projects or management actions made subject to this Act.

(B) No agency may follow the adaptive management track created by this Act if Congress [the legislature] has prohibited the use of that track in the legislation authorizing the agency to implement or engage in the project or management action or category of projects or management actions at issue.

(C) An agency must follow the adaptive management track created by this Act if Congress [the legislature] has expressly required the agency to follow that adaptive management track with respect to the project or management action or category of projects or management actions at issue.

(D) An agency may follow the adaptive management track created by this Act with respect to a specific project or specific management action, or a category of projects or management actions, if:

(1) Congress [The legislature] has not prohibited the use of the adaptive management track with respect to the specific project, management action, or category of projects or management actions; and

(2) the agency finds, on the basis of the best evidence available, that the project, management action, or category of projects or management actions:

a. deals with a complex system; 
b. involves a system for which the response to either stressors or management measures, or both, is difficult to predict, especially when development of more detailed information about the system could help future management actions and measures;

c. is subject to unknowns or uncertainties about the system, its stressors, and/or best management practices;

d. requires the agency to regulate or manage the complex system itself, or significant activities within or components of the system;

e. sets a definable overall goal for the system's management, or effectuates legislation or a rule that sets a definable overall goal or goals for the system's management;

f. provides or allows for identifiable indicators of progress and/or lack thereof toward the statutorily or regulatorily defined goal that can be reliably monitored and meaningfully measured;

g. allows for multiple management options and measures, so that adaptive management could help refine the management measures that the agency uses in future iterations of a management plan or project oversight; and

h. allows for observable system responses to stressors and/or management measures over ten years or less so that periodically reviewable adaptive management plans are possible.

(E) If an agency chooses, pursuant to section (D), to follow the adaptive management track created by this Act for a specific project, management action, or category of projects or management actions, it shall promulgate that decision through the notice-and-comment ("informal") rulemaking 
procedures identified in 5 U.S.C. $§ 553$ [state equivalent statute], except that the exceptions noted in that provision shall not apply to any decision made under this Section. Public participation shall be as allowed in 5 U.S.C. $\S 553$ [state equivalent statute]. Judicial review of the agency's decision shall be as allowed in $\S 6$ of this Act.

\section{Section 3: Initial Adaptive Management Plan}

\section{(A) Procedures Applicable to the Creation of the Initial Adaptive Management Plan}

(1) For any project or management action or category of projects or management actions properly utilizing the adaptive management track, the agency shall establish an initial adaptive management plan using the noticeand-comment ("informal") rulemaking procedures of 5 U.S.C. $\S 553$ [state equivalent statute], except that the exceptions noted in that provision shall not apply to any decision made under this section. Judicial review of the initial adaptive management plan shall be as specified in $\S 6$ of this Act.

(2) In addition, the agency shall, in designing its initial adaptive management plan, in providing public notice of its proposed initial adaptive management plan, and in providing opportunities for public comment on that proposed plan, make reasonable efforts to identify and offer reasonable opportunities for involvement to representatives of interested members of the public and relevant stakeholder groups. While the agency shall make reasonable efforts to invite and allow public participation from a balanced group of representatives of various aspects of the public interest in its project or management action or category of projects or management actions, the exact number of participating representatives and their final composition shall be left to the agency's sound discretion. 
(B) Components of the Initial Adaptive Management Plan

Every initial adaptive management plan shall contain detailed findings and determinations regarding each of the following plan components:

(1) Goals. The agency shall identify, as specifically as possible:

a. the overall management goal or goals for the system that it is managing;

b. the overall management goal or goals for the project, management action, or category of projects or management actions that it is undertaking through the adaptive management track;

c. the specific goals of the management measures that the agency will implement pursuant to its initial adaptive management plan;

d. the relationships among (1), (2), and (3); and

e. the relationships of each of (1), (2), and (3) to the relevant goals, objectives, requirements, and standards of the legislation that the agency is implementing through its project or management action or category of projects or management actions.

(2) Threats to Goals. The agency shall identify, as specifically as possible:

a. the existing and predicted stressors to the system that interfere with the management goal or goals for the system as a whole; for the project or management action or category of projects or management actions subject to the adaptive management track; and for the management measures to be implemented pursuant to the initial adaptive management plan;

b. the existing and predicted threats to the system, or to any of the system's components, that could 
compromise the success of the management measures to be implemented;

c. perturbations in the system that are occurring or might occur that could affect either the goal or the proposed management measures;

d. the agency's uncertainties regarding threats, stressors, and perturbations; and

d. the means by which the agency will be able to identify and address actual interference with its management goals and management measures from the stressors, threats, and perturbations that the agency has identified.

(3) Indicators for Monitoring. Using the best information available, the agency shall identify and explain:

a. the system indicators that will or could reveal the existing and changing relationships among the agency's management goals; threats, stressors, and perturbations of the system; and the agency's proposed management measures;

b. the indicators that the agency plans to monitor throughout its project or management action;

c. the past status of those indicators (if known);

d. the current status of those indicators;

e. the desired final goal or status for each indicator;

f. changes in indicator status that would indicate a positive change in the system being managed (i.e., a change that promotes the ultimate or immediate management goals) and at least one means of determining whether such changes are caused by the management measures that the agency has implemented; 
g. changes in indicator status that would indicate a negative change in the system being managed (i.e., a change that retards the ultimate or immediate management goals) and at least one means of determining whether such changes are caused by the management measures that the agency has implemented;

h. abort indicators - that is, threshold measurements or indicator statuses that, individually and collectively, indicate that the agency's current management measures should be terminated and a new adaptive management plan adopted; and

i. finished indicators - that is, threshold measurements or indicator statuses that, individually or collectively, signal that the agency's management measures have achieved the system benefits that they were intended to achieve.

\section{(4) Monitoring Plan}

a. The agency shall describe in detail its plan for systematically and consistently monitoring its chosen indicators using a uniform and scientifically defensible methodology, including its plan for collecting and reporting data. The agency shall explain how its monitoring plan accounts for stressors, threats, and perturbations and how the monitoring plan accurately assesses the entire system being managed in a comprehensive fashion.

b. The agency shall describe its plan for periodically releasing its monitoring data and reports on its implementation of the initial adaptive management plan to the public. The agency shall release all such data and reports to the public in a form that is both comprehensible to a lay citizen and utilizable by experts in the relevant field(s). Unless Congress [the legislature] specifies otherwise, the agency shall report its monitoring data to the public at least once every six months. Unless Congress [the legislature] 
specifies otherwise, the agency shall report on its implementation of the initial adaptive management plan at least yearly.

(5) Initial Management Measures. The agency shall describe in detail:

a. the initial set of management measures that it intends to implement and its reasons for choosing those measures;

b. the results that it expects from its initial management measures based on best information available;

c. system or component responses that will induce the agency to adjust its management measures, with explanations of why such system responses justify adjustment the management measures and of how the agency will make such adjustments to its management measures;

d. abort indicators - that is, threshold measurements or indicator statuses that, individually and collectively, signal that the agency's current management measures should be terminated and a new adaptive management plan adopted; and

e. finished indicators - that is, system responses and achieved indicator statuses that, individually or collectively, signal that the agency's management measures have achieved the system benefits that they were intended to achieve.

(6) Data and Report Release Schedule. The agency shall specify a schedule for releasing monitoring data to the public, with data releases to occur no less frequently than once every six (6) months. Monitoring data shall be released in the form specified in $\S 3(B)(4)$. The agency shall also specify a schedule for reporting to the public on its progress in implementing its adaptive management 
plan, with reports to issue no less frequently than once every year.

(7) Implementation Period. The agency shall designate the appropriate implementation period for its adaptive management plan as follows:

a. If Congress [the legislature] has specified an implementation period for the project, management action, or category of projects or management actions at issue, the agency shall adopt that implementation period and cite to the relevant legislation.

b. If Congress [the legislature] has not specified an implementation period for the project, management action, or category of projects or management actions at issue, the agency shall specify and justify an appropriate implementation based on the nature of the project or management action and the nature and duration of the management measures to be implemented. However, unless Congress [the legislature] has expressly allowed for longer implementation periods, no implementation period shall last longer than five (5) years, unless the agency can justify a longer period through clear and convincing evidence that a longer period is objectively necessary to meet statutory goals and objectives and defined management plan objectives.

\section{(C) Duration of the Initial Adaptive Management Plan}

(1) The agency's initial adaptive management plan shall remain active, and the agency shall continue to implement it, until the first of the following three termination points occurs:

a. the achievement of abort indicators that the agency identified pursuant to $\S \S 3(\mathrm{~B})(3)(\mathrm{h})$ and $(5)(\mathrm{D})$, unless the agency can attribute those statuses to the occurrence of an unexpected and temporary perturbation to the system whose effects are not expected to be permanent or long lasting; or 
b. the achievement of finished indicators that the agency identified pursuant to $\S \S 3(\mathrm{~B})(3)(\mathrm{i})$ and (5)(E), unless the agency attributes or should attribute those statuses entirely or significantly to a cause other than its own management measures; or

c. the ending of the implementation period that the agency identified pursuant to $\S 3(\mathrm{~B})(6)$.

(2) Notice of Termination. The agency shall publish notice of its intention to terminate the implementation of its initial adaptive management plan in the Federal Register [state equivalent]. Unless judicial review of the agency's decision is sought, the agency shall, at least thirty-one (31) days but not more than ninety (90) days after publication of the Federal Register termination notice, terminate implementation of the initial adaptive management plan and shall immediately proceed to adopt a new adaptive management plan pursuant to $\S 4$ of this Act. Judicial review of the agency's decision to terminate shall be in accordance with $\S 6$.

(3) Judicial Review. Judicial review of the agency's initial adaptive management plan shall be as specified in $\S 6$. However, unless the requirements of $\S 5$ are proven by clear and convincing evidence, there shall be no judicial review of the agency's implementation of its finalized initial adaptive management plan.

(4) Other Statutes and Procedures Not Applicable. Unless specified in the legislation authorizing the agency to undertake its project or management activities, no other statutes, regulations, or executive orders shall be deemed to impose any additional requirements, substantive or procedural, on the agency's creation or implementation of its initial adaptive management plan. 


\section{Section 4: Subsequent Adaptive Management Plans}

(A) An agency pursuing the adaptive management track with regard to a project, management action, or category of projects or management actions shall continue to adopt subsequent adaptive management plans until the agency can demonstrate that:

(1) Congress [the legislature] has expressly and specifically required that the agency terminate the adaptive management track for the project, management action, or category of projects or management actions at issue; or

(2) Congress [the legislature] required the agency to pursue the adaptive management track and the system has achieved the system status, indicator statuses, or management goals that Congress [the legislature] specified must be achieved in order for the adaptive management track to be terminated; or

(3) the agency chose to pursue the adaptive management track and the agency's management measures, management actions, and/or projects have generated all or a significant portion of the information required, resolved all or almost all of the management uncertainties, and stably achieved all of the management goals for the system; or

(4) the agency chose to pursue the adaptive management track and

a. repeated achievement of abort indicators; or

b. significantly changed circumstances in the system; or

c. significant new information about the system indicates that the agency's initial decision to pursue adaptive management for this project or management action or category of projects or management actions was in error or that effective adaptive management has become impossible or impracticable to implement for this system. 
(5) Any agency asserting that the circumstances of paragraph (1), (2), (3), or (4) have been met must justify its decision to remove its project, management action, or category of projects or management actions from the adaptive management track through a notice-andcomment ("informal") rulemaking pursuant to 5 U.S.C. $\S 553$ [state statutory equivalent], except that the exceptions noted in that provision shall not apply to any decision made under this section.

(5) Judicial review of an agency's decision to remove a project, management action, or category of projects or management actions from the adaptive management track shall be in accordance with $\S 6$ of this Act.

\section{(B) Adoption of Subsequent Adaptive Management Plans}

(1) Adoption through Rulemaking. The agency shall adopt any subsequent adaptive management plan using the notice-and-comment ("informal") rulemaking procedures of 5 U.S.C. $\S 553$ [state statutory equivalent], except that the exceptions noted in that provision shall not apply to any decision made under this section. Judicial review of any subsequent adaptive management plan shall be as specified in $\S 6$.

(2) Public Participation. In addition, the agency shall, in designing any subsequent adaptive management plan, in providing public notice of its proposed plan, and in providing opportunities for public comment on that proposed plan, make reasonable efforts to identify and offer reasonable opportunities for involvement to representatives of interested members of the public and relevant stakeholder groups. While the agency shall make reasonable efforts to invite and allow public participation from a balanced group of representatives of various aspects of the public interest in its project or management action or category of projects or management actions, the exact number of participating representatives and their final composition shall be left to the agency's sound discretion. 
(3) Components of a Subsequent Adaptive Management Plan

a. Every subsequent adaptive management plan shall contain all of the components specified in $\S 3(\mathrm{~B})$ of this Act.

b. In addition, each subsequent adaptive management plan shall also:

(i) Evaluate the monitoring data collected for the project, management action, or category of projects or management actions, both in the most recent implementation of the adaptive management process and over the course of the entire adaptive management process. Such evaluation should indicate whether the agency is making progress toward management goals and, if so, at what rate; analyze failures of progress; identify stressors, perturbations, or unexpected events that have affected the achievement of management objectives; and indicate whether the agency can confidently conclude that changes in indicator statuses are the result of the agency's management measures. The agency shall also consider whether new monitoring methodologies are appropriate, but if it chooses to adopt such new methodologies, it shall ensure that data already collected will be compatible with and comparable to data collected pursuant to the new methodologies.

(ii) Based on the data evaluation required in subparagraph (i), identify and explain any changes to the previous adaptive management plan or plans in light of new information, increased understanding of the system being managed, increased or decreased risks, increased or decreased uncertainties, significant changes to the system or its 
components, identification of the need to include more or different monitored indicators, or changes to the authorizing legislation. The agency must also justify any changes to its management goals and objectives with reference to its authorizing legislation.

(iii) Propose new management measures for the next implementation period, explaining why those management measures are appropriate, desirable, or required.

\section{(C) Duration of Each Subsequent Adaptive Management Plan}

(1) Each subsequent adaptive management plan shall remain active, and the agency shall continue to implement it, until the first of the following three termination points occurs:

a. the achievement of the abort indicators identified pursuant to $\S \S 3(\mathrm{~B})(3)(\mathrm{h})$ and $(5)(\mathrm{D})$, as made applicable to this section, unless the agency can attribute those statuses to the occurrence of an unexpected and temporary perturbation to the system whose effects are not expected to be permanent or long lasting; or

b. the achievement of the finished indicator statuses identified pursuant to $\S \S 3(\mathrm{~B})(3)(\mathrm{i})$ and (5)(E), as made applicable to this section, unless the agency attributes or should attribute those statuses entirely or significantly to a cause other than its own management measures; or

c. the ending of the implementation period that the agency identified pursuant to $\S 3(\mathrm{~B})(6)$, as made applicable to this section.

(2) Notice of Termination. The agency shall publish notice of its intention to terminate the implementation of its 
current adaptive management plan in the Federal Register [state equivalent]. Unless judicial review of the agency's decision is sought, the agency shall, at least thirty-one (31) days but not more than ninety (90) days after publication of the Federal Register termination notice, terminate implementation of the adaptive management plan and shall immediately proceed to adopt a new adaptive management plan pursuant to this section. Judicial review of the agency's decision to terminate shall be in accordance with $\S 6$.

(3) Judicial Review. Judicial review of any subsequent adaptive management plan adopted by the agency shall be as specified in $\S 6$. However, unless the requirements of $\S 5$ are proven through clear and convincing evidence, there shall be no judicial review of the agency's implementation of any finalized subsequent adaptive management plan.

(4) Other Statutes and Procedures Not Applicable. Unless expressly made applicable in the legislation authorizing the agency to undertake its project or management activities, no other statutes, regulations, or executive orders shall be deemed to impose any additional requirements, substantive or procedural, on the agency's creation or implementation of any subsequent adaptive management plan.

\section{Section 5: Termination of Adaptive Management Plan Implementation Because of Emergency Circumstances}

(A) This section applies only during the implementation period for a finalized adaptive management plan adopted pursuant to either $\S 3$ or $\S 4$.

(B) If the implementing agency concludes on the basis of its ongoing monitoring data that the system has achieved the abort indicators specified in the adaptive management plan, the agency shall, unless the agency can attribute those statuses to the occurrence of an unexpected and temporary perturbation to the system whose effects are not expected to be permanent or long lasting, immediately publish notice of its 
intention to terminate the implementation of that plan in the Federal Register [state equivalent]. Unless judicial review of the agency's decision is sought, the agency shall, at least thirty-one (31) days but not more than ninety (90) days after publication of the Federal Register termination notice, terminate implementation of the adaptive management plan and shall immediately proceed to adopt a new adaptive management plan pursuant to $\S 4$ of this Act. Judicial review of the agency's decision to terminate shall be in accordance with $\S 6$.

(C) If the agency can demonstrate by clear and convincing evidence that:

(1) the system has been subjected to a severe disruption that was not identified or anticipated in the adaptive management plan. "Severe disruptions" are limited to events such as natural disasters, economic collapses, or acts of war or terrorism; and

(2) as a result of the severe disruption, all or a significant portion of the informational bases that informed the agency's adaptive management plan are no longer true or accurate,

the agency may immediately publish notice of its intention to terminate the implementation of that plan in the Federal Register [state equivalent]. Unless judicial review of the agency's decision is sought, the agency shall, at least thirtyone (31) days but not more than ninety (90) days after publication of the Federal Register termination notice, terminate implementation of the adaptive management plan and shall immediately proceed to adopt a new adaptive management plan pursuant to $\S 4$ of this Act. Judicial review of the agency's decision to terminate shall be in accordance with $\S 6$.

(D) Any person may file a petition for mandamus in the U.S. District Court for the district in which the agency project or management action is occurring [state court], or in any U.S. District Court for a district in which the agency may be found 
[alternative state court], if the petitioner can prove by clear and convincing evidence that:

(1) the system that the agency is managing achieved the abort indicators specified in the currently applicable adaptive management plan;

(2) the system's achievement of the abort indicators cannot be attributed in whole or significant part to the occurrence of an unexpected and temporary perturbation to the system whose effects are not expected to be permanent or long lasting;

(3) the agency has not terminated and is not in the process of terminating its implementation of the adaptive management plan;

(4) the petitioner gave notice to the agency at least sixty (60) days before filing a mandamus action pursuant to this subsection that the system had achieved the abort indicators, with supporting documentation; and

(5) the system continues to exhibit the abort indicators identified in the adaptive management plan.

Upon a finding by the court that the petitioner has proven each of these requirements by clear and convincing evidence, the court shall order the agency to terminate its current adaptive management plan and proceed to the adoption of a subsequent adaptive management plan in accordance with $\S 4$.

(E) Any person may file a petition for mandamus in the U.S. District Court for the district in which the agency project or management action is occurring [state court], or in any U.S. District Court for a district in which the agency may be found [alternative state court], if the petitioner can prove by clear and convincing evidence that:

(1) the system that the agency is managing has been subjected to a severe disruption that was not identified or anticipated in the currently applicable adaptive management plan. "Severe disruptions" are limited to 
events such as natural disasters, economic collapses, or acts of war or terrorism; and

(2) as a direct result of the severe disruption, all or a significant portion of the informational bases that informed the agency's adaptive management plan are no longer true or accurate; and

(3) there is no valid reason for the agency to continue to implement its current adaptive management plan; and

(4) the agency has not terminated and is not in the process of terminating its implementation of the adaptive management plan; and

(5) the petitioner gave notice to the agency at least sixty (60) days before filing its mandamus action that the system had been subject to a severe disruption that warranted a new adaptive management plan, with supporting documentation; and

(6) the system continues to be disrupted as a direct result of the severe disruption identified.

The court shall presume that no unanticipated severe disruption has occurred and that neither termination of the plan's implementation nor mandamus is warranted. Upon a finding by the court that the petitioner has proven each of these requirements by clear and convincing evidence, the court shall order the agency to terminate its current adaptive management plan and proceed to the adoption of a subsequent adaptive management plan in accordance with $\S 4$. 


\section{Section 6: Judicial Review}

(A) If an agency chooses, pursuant to $\S 2(\mathrm{D})$ of this Act, to follow the adaptive management track when Congress does not explicitly require the agency to do so, or if any agency chooses pursuant to $\S 4(\mathrm{~A})$ of this Act to remove a project, management action, or category of projects or management action from the adaptive management track, any person may seek judicial review of the agency's final rule promulgating that decision in the United States Court of Appeals [state court] for: (1) the circuit in which the specific project or management action will occur, if the agency's decision pertains to only one specific project or management action; or (2) any circuit [district] in which the agency is found. Challenges to the agency's decision must be filed in the appropriate Court of Appeals [state court] within ninety (90) days of the publication in the Federal Register [state publication] of the agency's final rule announcing its decision. The reviewing court shall hold unlawful and set aside the agency's decision to follow the adaptive management track or to terminate the adaptive management track if that decision is found to be:

(1) contrary to Congress's [the legislature's] intent that the project, management action, or category of projects or management actions not be placed on the adaptive management track or not be removed from the adaptive management track, or otherwise not in accordance with law;

(2) arbitrary, capricious, or an abuse of discretion;

(3) in excess of statutory jurisdiction, authority, or limitations, or short of statutory right;

(4) without observance of procedure required by law; or

(5) contrary to constitutional right, power, privilege, or immunity.

(B) Any challenge to an agency's initial adaptive management plan adopted pursuant to $\S 3$ of this Act, and any challenge to an agency's subsequent adaptive management plan adopted 
pursuant to $\S 4$ of this Act must be filed with thirty (30) days of the publication of the final Federal Register notice for that plan in the United States Court of Appeals [state court] for (1) the circuit in which the specific project or management action will occur, if the agency's decision pertains to only one specific project or management action; or (2) any circuit [district] in which the agency is found. The reviewing court shall hold unlawful and set aside the agency's adaptive management plan if that plan is found to be:

(1) contrary to Congress's [the legislature's] goals or management specifications for the system, project, management action, or category of projects or management actions;

(2) arbitrary, capricious, or an abuse of discretion;

(3) without observance of procedure required by law; or

(4) contrary to constitutional right, power, privilege, or immunity.

In addition, the court in its sound discretion may award costs and reasonable attorney fees to the prevailing party.

(C) An agency's implementation of any adaptive management plan shall be deemed committed to agency discretion by law. Judicial review of such implementation shall not be allowed except as provided in $\S 5$ of this Act and by subsections (D), (E), $(\mathrm{F})$, and $(\mathrm{G})$ of this section. In addition, except as provided in subsection $(\mathrm{G})$ of this section, no court shall award costs or attorney fees to challengers/plaintiffs in any action brought to challenge or terminate an agency's implementation of its adaptive management plan.

(D) Petitioning parties seeking to terminate an agency's implementation of an adaptive management plan must proceed in accordance with $\S 5(\mathrm{D})$ or $\S 5(\mathrm{E})$ of this Act. The reviewing court shall presume that judicial review is inappropriate and unavailable, and it shall construe the mandamus exceptions provided in $\S 5$ narrowly. 
(E) Any person may challenge an agency's decision to terminate the implementation of an adaptive management plan pursuant to $\S \S 3(\mathrm{C})(1), 4(\mathrm{C})(1), 5(\mathrm{~B})$ or $5(\mathrm{C})$ of this Act within thirty (30) days of the agency's publication in the Federal Register [state equivalent] of its decision to terminate in the U.S. District Court for the district in which the agency project or management action is occurring [state court], or in any U.S. District Court for a district in which the agency may be found [alternative state court]. The court shall reverse the agency's decision to terminate and shall reinstate the previously operative adaptive management plan if the agency's decision to terminate was not supported by clear and convincing evidence that the requirements of $\S \S 3(\mathrm{C})(1), 4(\mathrm{C})(1), 5(\mathrm{~B})$ or $5(\mathrm{C})$ had been met.

(F) If an agency fails to release monitoring data or to publish an implementation report within sixty (60) days of the date specified in the adaptive management plan, any person may sue for the limited and exclusive purpose of compelling production of those data or that report. The complaint may be filed no sooner than sixty (60) days following the date specified in the adaptive management plan. The complaint may not be filed more than one hundred twenty (120) days after the date specified in the adaptive management plan to compel the release of a set of monitoring data or more than one hundred eighty (180) days after the date specified in the adaptive management plan to compel the release of an implementation report. In no case may a complaint be filed under this section if the implementation period for the current adaptive management plan has expired. Lawsuits initiated under this section shall be filed in the U.S. District Court for the district in which the agency project or management action is occurring [state court], or in any U.S. District Court for a district in which the agency may be found [alternative state court]. The court's review shall be strictly limited to (1) determining whether the agency has failed to release monitoring data or an implementation report according to the schedule specified in the current adaptive management plan; and (2) if so, ordering the agency to release such data or such implementation report within thirty (30) days of the court's order. 
(G) If an adaptive management plan specifies an implementation period of three (3) years or longer, and the agency has taken absolutely no action to implement the plan for at least two (2) years, any person may challenge the agency's absolute lack of implementation in the U.S. District Court for the district in which the agency project or management action is occurring [state court], or in any U.S. District Court for a district in which the agency may be found [alternative state court]. The court shall dismiss the lawsuit immediately upon the agency's proffer of evidence that:

(1) the implementation period will or did not last longer than three (3) years; or

(2) the adaptive management plan at issue has terminated or is being terminated; or

(3) the agency is engaged in ongoing monitoring or data collection in accordance with the adaptive management plan; or

(4) the agency has released monitoring data to the public at least once in the last two (2) years; or

(5) the agency has published an implementation report at least once in the last two (2) years; or

(6) the agency has implemented or has begun to implement a management activity specified in the adaptive management plan at least once in the last two (2) years; or

(7) the agency has undertaken any other activity within the last two (2) years that indicates that it has not completely abandoned the adaptive management plan.

Any agency securing a dismissal under this section shall be entitled to an award of its costs and reasonable attorney fees, and, in the court's discretion, the plaintiff(s) may be subject to sanctions for bringing a frivolous lawsuit. If the implementation period is three (3) years or longer, the adaptive management plan has not been terminated and is not 
in the process of being terminated, and the agency proffers no evidence of active implementation as specified, the court shall, in its sound discretion, either (1) order the agency to implement the adaptive management plan; (2) terminate the current adaptive management plan and order the agency to adopt a new adaptive management plan; or (3) terminate the current adaptive management plan and terminate the agency's participation in the adaptive management track. Plaintiff(s) securing such an order under this section shall be entitled to an award of costs and reasonable attorney fees. 